\title{
Characterization of Two Unusual Features of Resistance to Soilborne cereal mosaic virus in Hexaploid Wheat: Leakiness and Gradual Elimination of Viral Coat Protein from Infected Root Tissues
}

\author{
Rebecca Lyons, ${ }^{1}$ Nazli D. Kutluk Yilmaz, ${ }^{2}$ Stephen Powers,${ }^{3}$ Kim E. Hammond-Kosack, ${ }^{1}$ and \\ Kostya Kanyuka ${ }^{1}$ \\ ${ }^{1}$ Center for Sustainable Pest and Disease Management, Department of Plant Pathology and Microbiology, Rothamsted \\ Research, Harpenden, Hertfordshire, AL5 2JQ, U.K.; ${ }^{2}$ Department of Plant Protection, Faculty of Agriculture, Ondokuz \\ Mayis University, Samsun, 55139, Turkey; ${ }^{3}$ Center for Mathematical and Computational Biology, Department of \\ Biomathematics and Bioinformatics, Rothamsted Research, Harpenden, Hertfordshire, AL5 2JQ, U.K.
}

Submitted 16 December 2008. Accepted 23 January 2009.

Spatiotemporal infection patterns of Soilborne cereal mosaic virus (SBCMV) were compared between resistant and susceptible wheat cultivars to elucidate disease resistance mechanisms. Resistance to SBCMV was manifested by a gradual disappearance of the viral coat protein (CP) from the roots following an initial short period of steady accumulation. Interestingly, viral RNA persisted in the roots of resistant cultivars even after the $C P$ had disappeared. Traces of viral RNA were also detected in the uninoculated leaves of the resistant cv. Cadenza. These findings suggest that the resistance mechanism to SBCMV in wheat involves the efficient disassembly of virus particles and either an inhibition of further synthesis of viral $\mathrm{CP}$ or its proteolytic degradation. SBCMV accumulated in the leaves of a small proportion of individual plants of Cadenza and other recognized resistant cultivars, highlighting the leaky nature of the resistance, but the roots of these plants were often devoid of viral CP. Increasing or decreasing the concentration of the inocula had no effect on the incidence rate of such "resistance breakdown"; however, a positive correlation was found between the incidence rate of resistance breakdown and the percentage of systemically infected individuals of recognized susceptible cultivars in each separate experiment.

Soilborne cereal mosaic virus (SBCMV) causes disease on wheat, rye, and triticale in Europe (Koenig and Huth 2000). SBCMV is closely related to another member of the genus Furovirus, Soilborne wheat mosaic virus (SBWMV), which causes a disease with similar symptoms but is more widely distributed throughout the world (Brakke and Landenberg 1988; Gill 2004; Hariri and Meyer 2007; Kapooria et al. 2000; Koenig and Huth 2003). Both viruses are transmitted to the roots of host plants by the plasmodiophorid Polymyxa graminis. In susceptible winter wheat cultivars, the virus is transmitted to the roots in the autumn and then it is translo-

Corresponding author: K. Kanyuka; E-mail: kostya.kanyuka@bbsrc.ac.uk

* The $\boldsymbol{e}$-Xtra logo stands for "electronic extra" and indicates that two supplemental figures and four supplemental tables are published online. Also, Figures 2, 4, and 7 appear in color online. cated to the stem and leaves in the spring, where it causes disease. Yield losses of up to $80 \%$ have been reported from SBWMV in the United States (Hunger et al. 1989; McKinney 1937), and SBCMV is becoming an increasingly economically important pathogen in Europe (Vallega et al. 1999).

Resistance to SBCMV in the U.K. wheat cv. Cadenza is conferred by a single genetic locus, Sbml (Bass et al. 2006). Other studies have suggested alternate modes of genetic control of resistance to SBWMV (Barbosa et al. 2001; Modawi et al. 1982; Nakagawa et al. 1959) but, as yet, the gene or genes conferring resistance to SBCMV and SBWMV have not been cloned. Resistance to SBCMV and SBWMV in wheat is thought to operate by restricting the upward, root-to-shoot virus translocation within the plant. This type of resistance is termed "translocation resistance" (Driskel et al. 2002; Huth et al. 2007; Myers et al. 1993). Wheat cultivars possessing translocation resistance to SBWMV behave as fully susceptible when the virus is artificially inoculated onto the leaves: the virus is able to spread systemically from the inoculated leaves to the young uninoculated leaves as well as to the roots (Driskel et al. 2002; McKinney 1948; Myers et al. 1993). The most likely route of the virus systemic spread from the primary inoculated leaves is via the phloem, whereas it has been suggested that SBWMV may travel from roots to shoots and leaves via the xylem (Verchot et al. 2001). Therefore, restriction of upward virus translocation in resistant wheat cultivars could be due to a block on virus entry or exit from the xylem. However, there is no direct evidence to support this hypothesis.

Translocation resistance is not unique to the wheat-Furovirus pathosystem. A block on virus translocation from root to shoot has also been proposed as a mechanism of resistance to P. graminis-transmitted Bymovirus spp. Barley yellow mosaic virus (BaYMV) and Wheat spindle streak mosaic virus (WSSMV) in barley cultivars carrying rym7, rym8, or rym10 resistance genes (McGrann and Adams 2004) and in wheat cultivars carrying the major resistance gene on chromosome 2D (Carroll et al. 2002; Khan et al. 2000), respectively.

A reduction or delay in viral accumulation in the roots or resistance to viruliferous $P$. graminis zoospores have been proposed as additional or alternative mechanisms of resistance to SBCMV or SBWMV in hexaploid bread wheat and in tetraploid durum wheat (Hariri et al. 1987; Himmel et al. 1991; Hunger et al. 1989; Larsen et al. 1985). Studies of other virus- 
plant interactions have shown that initial viral replication or movement is delayed or inhibited in resistant cultivars when compared with susceptible cultivars (Chain et al. 2005; Kumari and Makkouk 2003) but it is not known whether such a phenomenon occurs in SBCMV-resistant wheat cultivars.

Previously, we observed that viral coat protein $(\mathrm{CP})$ was detectable in the leaves of a small proportion of individual plants of the recognized resistant wheat cvs. Cadenza and Claire following inoculation with SBCMV-infested soil from Wiltshire, U.K. under glasshouse conditions (R. Lyons, unpublished data). In contrast, such a "breakdown of resistance" was not observed when these cultivars were inoculated with the SBCMV-infested soil from Kent, U.K. (K. Kanyuka, unpublished data). We speculated that such a differential response might be due to differences between genomes of SBCMV-Wilt and SBCMVKent. This hypothesis is valid because naturally occurring isolates of other Polymyxa spp.-transmitted viruses such as BaYMV (Hariri et al. 2003), Barley mild mosaic virus (BaMMV) (Kühne et al. 2003), and Beet necrotic yellow vein virus (BNYVV) (Liu and Lewellen 2007; Varrelmann 2007), which are able to overcome host resistance, have been described. Several reports demonstrate that SBWMV could also be detected in leaves of a small proportion of individuals of resistant wheat cultivars either when inoculated with infested soils under glasshouse conditions or when grown in naturally infested fields (Armitage et al. 1990; Driskel et al. 2002; Himmel et al. 1991). Similar observations were reported from wheat germplasm resistance screenings in SBCMV-infested fields in France, Germany, and Italy (Budge et al. 2008) (U. Kastirr, personal communication).

$P$. graminis is known to be erratically distributed in infested soils (Ward et al. 2005). In field-based screens as well as in glasshouse-based resistance tests involving inoculation with infested soils, the possibility exists that the roots of individual plants are exposed to different local concentrations of viruliferous $P$. graminis. Therefore, breakdown of resistance in a small proportion of individuals could potentially be due to exposure of their roots to excessively high localized concentrations of virus-containing $P$. graminis.

Resistance to SBWMV or SBCMV in certain wheat cultivars such as Newton is overcome by mixed infection with WSSMV, which is also vectored by $P$. graminis (Cadle-Davidson et al. 2006; Lapierre et al. 1995; Lommel and Willis 1984; Lommel et al. 1986). WSSMV-Furovirus associations have also been reported from China (Chen 1993), Africa (Kapooria et al. 2000), and Europe (Hariri et al. 1987; Lapierre et al. 1995; Rubies-Autonell and Vallega 1987). Thus, the potential presence of WSSMV in the SBCMV-infested soil from Wiltshire may also explain the breakdown of SBCMV-resistance observed in a small proportion of individuals of resistant wheat Cadenza and other recognized resistant wheat cultivars.
This study had two main objectives. The first was to determine the incidence rate of resistance breakdown in U.K. SBCMV-resistant wheat cultivars and to investigate factors influencing this phenomenon. Three main hypotheses were tested: the breakdown of resistance is due to i) the emergence of a new resistance-breaking variant of SBCMV in Wiltshire, U.K. soil; ii) an increased concentration of starting inoculum; or iii) co-infection with WSSMV. The second objective was to explore the mechanisms of resistance and the breakdown of resistance in hexaploid wheat by comparing spatiotemporal SBCMV infection patterns in resistant and susceptible cultivars.

\section{RESULTS}

\section{The incidence rate of translocation resistance breakdown in recognized resistant cultivars is not correlated with the SBCMV isolate or the concentration of the soil inocula used.}

Three resistant wheat cultivars (Cadenza, Claire, and Cardinal) and two susceptible wheat cultivars (Consort and Avalon) were inoculated with the three SBCMV-infested soils (SBCMV-Kent02, SBCMV-Wilt04, and SBCMV-Wilt05) under glasshouse conditions. Each cultivar was inoculated with each of the three soils mixed with sand in ratios of $1: 2,1: 5$, $1: 10$, and 1:20. Leaves of individual plants were tested for the presence of SBCMV CP using enzyme-linked immunosorbent assay (ELISA) at three timepoints between 6 and 11 weeks postinoculation (wpi).

In this experiment (hereafter referred to as experiment 1), 94\% of Consort and Avalon plants inoculated with the SBCMV-Wilt05 soil contained viral CP in the leaves. In contrast, only approximately $50 \%$ of Consort and Avalon plants inoculated with SBCMV-Kent02 or SBCMV-Wilt04 soil contained SBCMV CP in the leaves (Table 1; Supplementary Table 1). Viral CP was also detected in the leaves of a small proportion of Cadenza, Cardinal, and Claire plants inoculated with either SBCMV-Wilt04 or SBCMV-Wilt05 soil, but viral $\mathrm{CP}$ was absent from the leaves of all individuals of these cultivars inoculated with the SBCMV-Kent02 soil. The data obtained in this experiment was fitted to a generalized linear model and this revealed that, as expected, soil and wheat cultivar were two factors that significantly influenced the probability of systemic virus infection $(P<0.001)$. Although these data suggested that resistant wheat cultivars may respond differentially to SBCMV isolates from Kent and Wiltshire, there was no significant differential cultivar response to the different soils $(P=0.085)$. In addition, there was no correlation between the dilution rate of soil inocula and the incidence rate of resistance breakdown $(P=0.089)$. Therefore, the data obtained in experiment 1 did not support two of our initial hypotheses (i.e., that the breakdown of resistance is due to either the emer-

Table 1. Positive correlation between the incidence rate of infection of recognized susceptible wheat cultivars and the occurrence of resistance breakdown in recognized resistant wheat cultivars ${ }^{\mathrm{a}}$

\begin{tabular}{|c|c|c|c|c|c|c|}
\hline \multirow[b]{3}{*}{ Soil batch } & \multirow[b]{3}{*}{ Experiment } & \multicolumn{4}{|c|}{ Probability of systemic infection } & \multirow[b]{3}{*}{ Resistance breakdown } \\
\hline & & \multicolumn{2}{|c|}{ Avalon } & \multicolumn{2}{|c|}{ Consort } & \\
\hline & & Mean & Standard error & Mean & Standard error & \\
\hline \multirow[t]{2}{*}{ Kent02 } & 1 & 0.36 & 0.09 & 0.50 & 0.10 & - \\
\hline & 2 & 0.71 & 0.08 & 0.81 & 0.07 & + \\
\hline \multirow[t]{2}{*}{ Wilt04 } & 1 & 0.56 & 0.09 & 0.69 & 0.08 & + \\
\hline & 2 & 0.21 & 0.08 & 0.32 & 0.10 & - \\
\hline \multirow[t]{2}{*}{ Wilt05 } & 1 & 0.83 & 0.06 & 0.90 & 0.04 & + \\
\hline & 2 & 0.33 & 0.10 & 0.47 & 0.11 & - \\
\hline
\end{tabular}

\footnotetext{
${ }^{a}$ Probability values were predicted from fitting the data from soil-inoculation experiments 1 and 2 to a generalized linear model.

$\mathrm{b}_{-}=$absence of Soilborne cereal mosaic virus coat protein (SBCMV CP) in leaves of all tested individuals of resistant wheat cvs. Cadenza, Claire, or Cardinal and $+=$ presence of SBCMV CP in leaves of at least one individual of either cv. Cadenza, Claire, or Cardinal.
} 
gence of a new resistance-breaking variant of SBCMV in Wiltshire soil or an increased concentration of starting inoculum).

To confirm the finding that each cultivar responded similarly to inoculation with viruliferous soils from Wiltshire and Kent, an additional soil-inoculation experiment (hereafter referred to as experiment 2) was undertaken. The statistical analysis of the data from experiment 1 suggested that the incidence rate of leaf infection in both susceptible and resistant cultivars was not significantly affected when the soil inocula were diluted with sand between 3 and 21 times $(P=0.089)$. Therefore, in experiment 2 , a single viruliferous soil/sand ratio of 1:10 was used for plant inoculation. In contrast to experiment 1 , translocation resistance to SBCMV was overcome in $16 \%$ of Cadenza and $25 \%$ of Claire individuals inoculated with the SBCMVKent02 soil (Table 2; Supplementary Table 2) in experiment 2. These data indicated that resistance could be overcome by both Wiltshire and Kent isolates of SBCMV.

\section{Incidence rate of translocation resistance breakdown is positively correlated with the percentage of systemically infected individuals of recognized susceptible cultivars in each separate experiment.}

Data from both soil-inoculation experiments were modeled together, taking all three soils and two experimental replicates into account. The predicted probability of leaf infection occurring in susceptible cultivars Consort and Avalon was significantly higher than in resistant cultivars Cardinal, Claire, and Cadenza $(P<0.05)$ (Supplementary Fig. 1). There was very little difference in the probability of leaf infection between the three resistant cultivars or between the two susceptible cultivars. This analysis confirmed that U.K. wheat cultivars respond as two distinct groups and that Claire, Cadenza, and Cardinal should remain classified as resistant. A similar system of resistance rating based on disease incidence was used to assess SBWMV resistance in small grain cereals in the United States (Cadle-Davidson et al. 2006).

As well as the overall differences between the cultivars, the modeling confirmed that there was a significant interaction between soil and experiment $(P<0.01)$ (i.e., that the inoculum potential of each batch of viruliferous soil differed between experiment 1 and experiment 2) (Table 1). However, these effects were independent of the cultivar effect because there were no significant interactions of wheat cultivar with soil or experiment $(P>0.05)$.

Importantly, there was a positive correlation between the incidence rate of systemic SBCMV infection in susceptible wheat cultivars and the incidence rate of resistance breakdown in the resistant cultivars. In other words, for each separate soilinoculation experiment, it was possible to predict whether the

Table 2. Incidence rate of systemic Soilborne cereal mosaic virus (SBCMV) infection in soil-inoculated recognized susceptible (S) and resistant (R) wheat cultivars ${ }^{\mathrm{a}}$

\begin{tabular}{lccc}
\hline Cultivar & Tested $^{\mathbf{b}}$ & No. infected $^{\mathbf{c}}$ & ${\text { Infected }(\%)^{\mathbf{d}}}^{\text {Consort (S) }}$ \\
\hline Avalon (S) & 114 & 74 & 65 \\
Claire (R) & 92 & 51 & 55 \\
Cadenza (R) & 90 & 11 & 12 \\
Cardinal (R) & 136 & 13 & 10 \\
\hline
\end{tabular}

${ }^{a}$ Data correspond to soil-inoculated individuals sampled at 7 weeks postinoculation and later timepoints and tested for the presence of SBCMV either using tissue-print immunoassay or enzyme-linked immunosorbent assay.

b Total number of tested individual plants.

${ }^{c}$ Number of individual plants that contained SBCMV coat protein (CP) in the leaves.

${ }^{\mathrm{d}}$ Percentage of individual plants that contained SBCMV CP in the leaves. resistance breakdown was likely to occur or not based on the observed percentage of systemically infected individuals of susceptible cultivars. Individuals of resistant wheat cultivars (e.g., Cadenza) contained SBCMV CP in their leaves when the soil inoculum and environmental conditions were capable of causing systemic infection in $\geq 56 \%$ of individuals of susceptible wheat Avalon or Consort. However, when less than $56 \%$ of individuals of these susceptible genotypes were systemically infected, leaves of all individuals of resistant wheat cultivars were virus free (Table 1).

\section{The incidence of resistance breakdown in recognized resistant cultivars and concentration of $\boldsymbol{P}$. graminis in their roots are uncorrelated.}

$P$. graminis is known to be nonuniformly distributed through the soil (Ward et al. 2005). Therefore, individual test pots from the soil-inoculation experiments 1 and 2 may have contained different total or local concentrations of viruliferous $P$. graminis. Intriguingly, following inoculation with viruliferous soils, some individuals of resistant cultivars contained SBCMV CP in their leaves whereas others did not, sometimes even when these individuals were grown in the same inoculation pot (Tables 1 and 2).

A quantitative polymerase chain reaction (qPCR) was undertaken to compare the concentration of $P$. graminis present in roots of soil-inoculated individuals. For each comparison, three to four individuals of each cultivar grown in the same inoculation pot, but which either contained or lacked SBCMV $\mathrm{CP}$ in their leaves, were selected. $P$. graminis DNA was not detected in healthy wheat roots, whereas roots of all soilinoculated plants contained $P$. graminis. The concentration of P. graminis in the infected roots ranged from 34.19 to 160.73 pg per $100 \mathrm{ng}$ of wheat root DNA (Fig. 1). For each soil, there was no correlation between the inocula dilution factors and the concentration of $P$. graminis in the corresponding infected plant root samples. Importantly, there was no correlation between the $P$. graminis concentrations in the roots of individual plants of resistant wheat cultivars and the presence of SBCMV $\mathrm{CP}$ in their leaves. Therefore, the breakdown of resistance to SBCMV in our glasshouse-based soil-inoculation experiments does not seem to have been due to a higher $P$. graminis concentration in the applied soil inocula.

\section{WSSMV is not present}

in two different U.K. SBCMV-infested soils.

In the United States and several European countries (e.g., France and Italy), SBCMV and SBWMV are often found in mixed infections with a Bymovirus sp., WSSMV (Budge et al. 2008; Lapierre et al. 1995; Lommel and Willis 1984). It has been previously suggested that WSSMV may compromise host resistance to SBWMV or SBCMV (Lommel and Willis 1984; Lommel et al. 1986). Inspection of sap from SBCMV-containing leaves of resistant wheat cvs. Cadenza and Claire and susceptible Consort plants inoculated with SBCMV-Wilt04 soil using transmission electron microscopy (TEM) revealed the presence of stiff, rod-shaped virus particles with dimensions characteristic of furoviruses. Long, flexuous, filamentous particles typical of WSSMV were not detected in inspected samples (data not shown). Using reverse-transcription (RT)-PCR, WSSMV was also undetected in leaves of both SBCMV-resistant and SBCMV-susceptible cultivars inoculated with viruliferous soils from Kent and Wiltshire (Supplementary Fig. 2). Therefore, breakdown of resistance to SBCMV in the recognized resistant wheat genotypes observed in experiments 1 and 2 was not the result of co-infection with WSSMV. In addition to SBCMV particles, we also identified isometric virus particles, approximately $30 \mathrm{~nm}$ in diameter, in the roots of some sus- 
ceptible Consort plants. These were possibly Cocksfoot mottle virus (CfMV), a Sobemovirus sp. which is known to occur in central and southern England on several species of Gramineae (Sergeant 1964). It is not known whether CfMV is able to compromise resistance to furoviruses in wheat.

Different spatiotemporal distribution of SBCMV in both roots and leaves of soil-inoculated recognized resistant versus recognized susceptible cultivars.

As described above, SBCMV CP was detected by ELISA in the leaves of a small proportion of individuals of resistant cvs. Cadenza, Claire, and Cardinal inoculated with viruliferous soils under glasshouse conditions. The viral CP in the leaves of these cultivars was usually detectable by ELISA only after 8 to 12 wpi, whereas it was detected in the leaves of susceptible cvs. Avalon and Consort as early as at 6 to 7 wpi (Tables 1 and 2). In soil-inoculation experiments 1 and 2, the plants were subjected to the first ELISA tests at 6 or 7 wpi. Thus, possibly, the SBCMV was present in the leaves of susceptible cultivars at even earlier timepoints postinoculation (i.e., prior to the time of the first scheduled ELISA test). To test this hypothesis and to study the timing of SBCMV CP translocation from root to shoot, another soil-inoculation experiment (hereafter referred to as the time-course experiment) was carried out. In this experiment, the spatiotemporal distribution of SBCMV CP and SBCMV genomic RNA in susceptible and resistant wheat cultivars was analyzed using tissue-print immunoassay (TPIA) and qRT-PCR, respectively.

One week postinoculation with the SBCMV-Wilt soil, viral $\mathrm{CP}$ was detectable in the roots of individuals of the three wheat cvs. Cadenza (resistant), Oasis (resistant), and Consort (susceptible), which were subjected to the TPIA time course analysis. SBCMV CP accumulated throughout the roots of Consort plants at each subsequent test timepoint (Fig. 2). In contrast, the host response of the majority (92\%) of Cadenza and Oasis individuals to SBCMV was manifested by a gradual disappearance of SBCMV CP from the infected roots after an initial period of progressive accumulation (Figs. 2 and 3). The predominant distribution pattern observed in $\mathrm{Ca}-$ denza and Oasis plants was that viral CP ceased accumulating after approximately 6 wpi and, by 12 wpi and later timepoints, viral CP was either undetectable or present at greatly reduced levels. In $20 \%$ of Cadenza plants examined at 7 wpi and at later timepoints, SBCMV CP was detectable only in the crown but not in the younger roots or aboveground tissues. These data support the hypothesis that resistance to furoviruses in wheat is due to a block on virus translocation from roots to shoots (Driskel et al. 2002; Huth et al. 2005). The decline in the amount of SBCMV CP detectable by TPIA in resistant cvs. Oasis and Cadenza after approximately 6 to 10 wpi suggests that the encapsidation of viral RNA was greatly reduced or completely prevented from approximately 6 to $10 \mathrm{wpi}$ onward. The apparent disappearance of SBCMV $\mathrm{CP}$ from the roots by 12 wpi may also be explained by the reduced density of virus particles within the expanding root biomass dropping below the threshold of detection by TPIA, or by host resistance-induced proteolytic degradation of the viral $\mathrm{CP}$ and possibly also viral RNA.

When sap extracted from the roots of SBCMV-infested soilinoculated resistant Cadenza and susceptible Consort plants collected at $3,4,8,10,12$, and 15 wpi was examined by TEM, stiff, rod-shaped particles approximately $18 \mathrm{~nm}$ in diameter typical of a Furovirus sp. were observed in all Consort root preparations except for plants collected at 4 wpi. Stiff rods approximately $18 \mathrm{~nm}$ in diameter were observed in Cadenza roots collected at 6 wpi but not at any of the other timepoints tested. The axial canal of all virus particles was obvious and there was no evidence of virus particle degradation. The viral rod length ranged from 45 to $400 \mathrm{~nm}$ (R. Lyons, unpublished data).

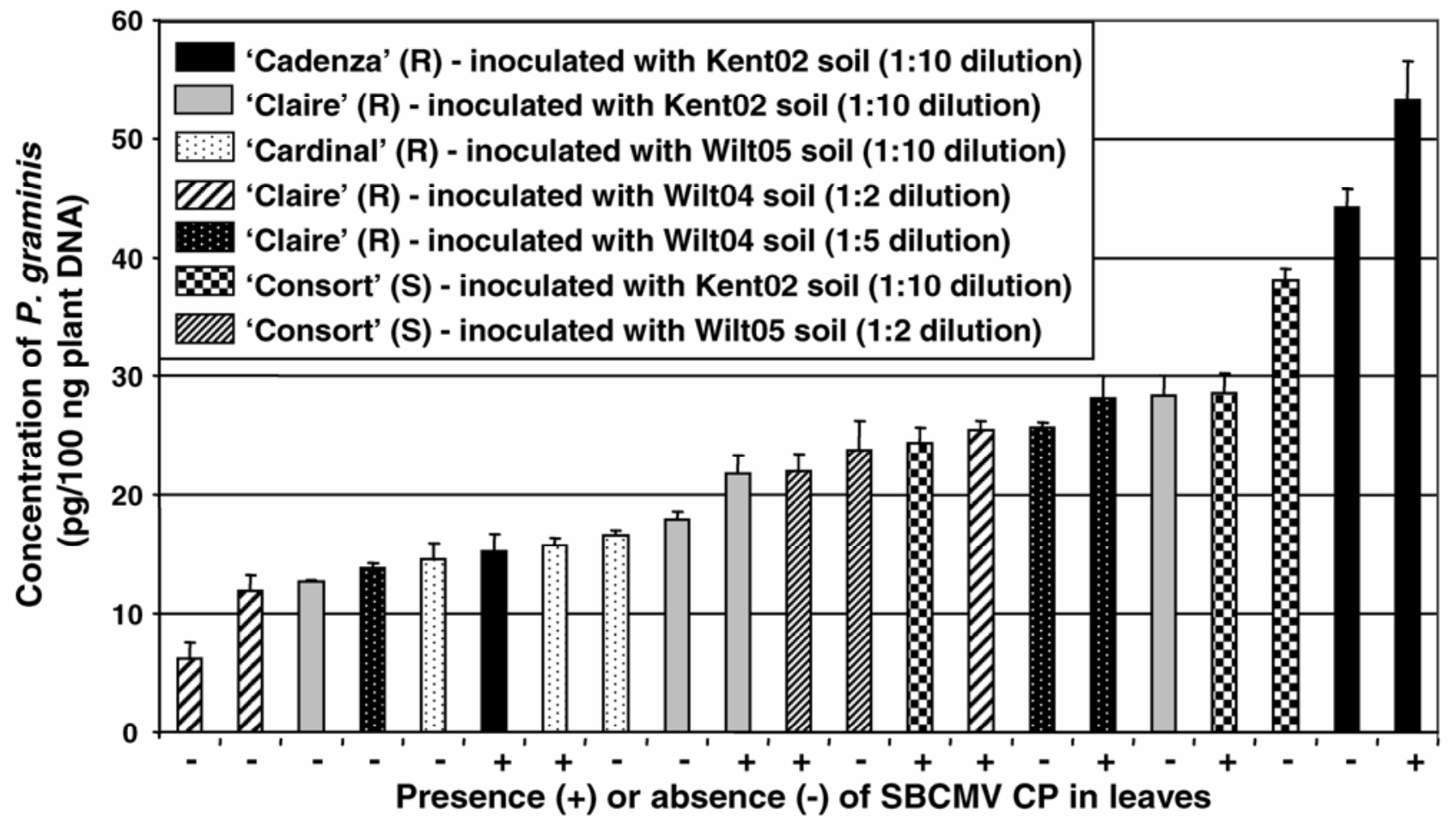

Fig. 1. Quantification of Polymyxa graminis in wheat roots using quantitative polymerase chain reaction (qPCR). The concentration of $P$. graminis in the roots is expressed in picograms per $100 \mathrm{ng}$ of wheat root DNA. Each bar represents the qPCR data for one individual plant. The standard error is represented by the error bars for the mean of two technical replicates. Each pattern corresponds to one set of plants grown in the same inoculation pot. The presence $(+)$ or absence (-) of Soilborne cereal mosaic virus coat protein (SBCMV CP) in the leaves is shown for each plant. All plants were sampled at 14 weeks postinoculation. 
SBCMV CP gradually disappears from the roots of soil-inoculated recognized resistant but not recognized susceptible cultivars.

Similarly to the ELISA data from soil-inoculation experiments 1 and 2 (Tables 1 and 2), SBCMV CP was detected in the leaves and upper stem of $17 \%$ of Cadenza (resistant) individuals and $14 \%$ of Oasis (resistant) individuals between 7 and 17 wpi in the time-course experiment (Fig. 3). Two Cadenza individuals and one Oasis individual containing viral $\mathrm{CP}$ in the leaves also contained viral $\mathrm{CP}$ in the roots at 12 wpi. However, SBCMV CP was not detected in the roots of the other six Cadenza and two Oasis individuals containing viral $\mathrm{CP}$ in the leaves (Fig. 3). In one Oasis individual sampled at 12 wpi, viral $\mathrm{CP}$ was detected in the tillers but not in leaves on the main stem. Tillers develop their own root system which is independent from that of the main stem (Percival 1921). Therefore, the virus detected in this individual was likely to have been transported upward into the tillers from the younger infected root tissues rather than from the aerial tissues.

Oasis is a winter wheat whereas Cadenza is a facultative wheat cultivar. Both these resistant genotypes showed similar spatiotemporal distribution of SBCMV CP. Therefore, it seemed unlikely that the growth habit of wheat had an impact on the resistance response to SBCMV, at least under the conditions used in this study. To verify this conclusion, we investigated responses to SBCMV of additional wheat cultivars with different growth habits during the later stages of infection. Resistant cvs. Claire (winter wheat) and Cardinal (spring wheat) and susceptible winter cvs. Robigus and Avalon collected from the soil-inoculation experiments 1 and 2 were subjected to TPIA at 12 to 15 wpi (Fig. 4). The distribution of SBCMV CP in tissues of Claire and Cardinal at 12 to 15 wpi was similar to that of Oasis and Cadenza. That is, although viral CP was ubiquitously distributed throughout the roots of the susceptible cvs. Avalon, Robigus, and Consort by 12 wpi (Figs. 3 and 4), SBCMV CP was reduced or undetectable in both roots and leaves of the majority of Claire and Cardinal individuals at 12 wpi and later timepoints postinoculation (Figs 3 and 4). All Claire and Cardinal individuals containing SBCMV CP in the leaves lacked SBCMV CP in the roots (Figs. 3 and 4), except for one Claire individual sampled at $12 \mathrm{wpi}$, which contained SBCMV CP in both leaves and roots (data not shown).
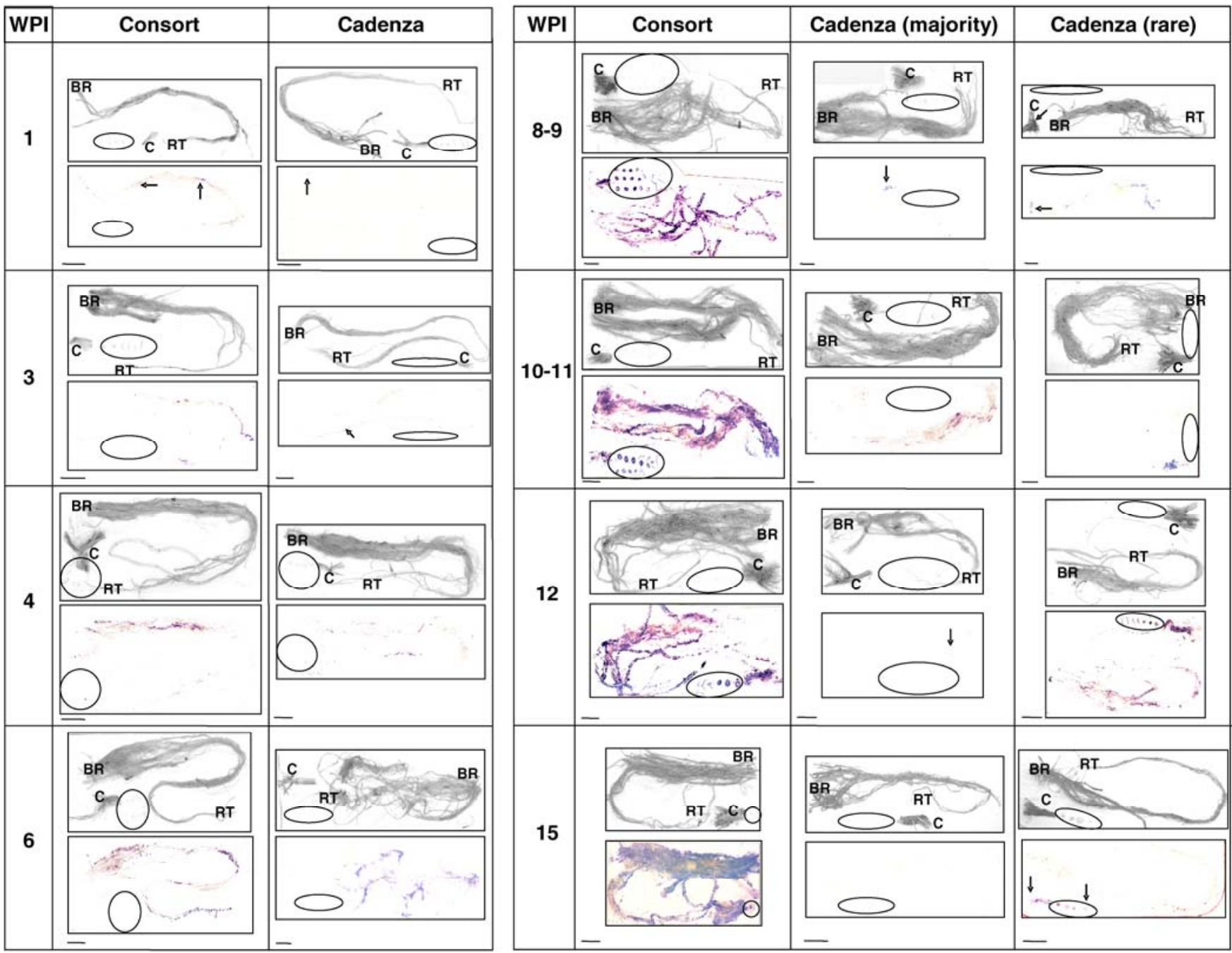

Fig. 2. Examples of tissue-print immunoassays (TPIA) for the detection of Soilborne cereal mosaic virus coat protein (SBCMV CP) in soil-inoculated Cadenza (resistant) and Consort (susceptible) plants at eight timepoints over the period from 1 to 15 weeks postinoculation (wpi). Each square panel shows a representative Cadenza or Consort plant sampled at the timepoint (wpi) indicated to the left. The top image for each plant shows the position of basal roots (BR), root tips (RT), crown (C), and stem and leaf cross sections (circled). The bottom image for each plant shows the localization of SBCMV CP (purple coloration). Where purple coloration is minimal, its location is indicated with a black arrow. TPIA data for Cadenza at 8 wpi and at later timepoints are shown in two columns. The left column shows TPIA data corresponding to the pattern of SBCMV CP accumulation in the majority of Cadenza individuals. The right column displays TPIA data for the rare Cadenza individuals in which the resistance to SBCMV had been overcome. A $1-\mathrm{cm}$ scale bar is shown in the bottom left corner of each panel. 
Collectively, these data suggest that the gradual disappearance of SBCMV CP from the roots and the infrequent infection of aerial parts of the plant is a phenomenon that is common to resistant cultivars with different growth habits. The presence of SBCMV CP in the leaves of both resistant and susceptible wheat cultivars almost always coincided with typical virus-induced symptoms (i.e., the mosaic or mottling of the leaves). Individual plants whose leaves tested negative by ELISA displayed no viral symptoms.

By 8 wpi, the amount of SBCMV CP detected in the roots of soil-inoculated Cadenza and Claire was negligible compared with Consort and Avalon (Fig. 4). Other low and higher mo- lecular weight viral $\mathrm{CP}$-related protein products (i.e., possible proteolytic degradation intermediates and post-translationally modified protein products, respectively) were absent in total protein preparations from the roots of resistant cultivars at earlier timepoints tested (data not shown).

Summarizing data from the soil-inoculation experiments 1 and 2 and from the timecourse experiment (Fig. 4), 55 to $65 \%$ of plants of the recognized susceptible cvs. Avalon or Consort contained SBCMV CP in the leaves when assessed between 7 and 17 wpi. In contrast, leaves of only 4 to $12 \%$ of the recognized resistant cvs. Claire, Cadenza, or Cardinal contained SBCMV $\mathrm{CP}$ in the leaves at 7 wpi and later timepoints (Table 2).

\section{A Susceptible genotypes}

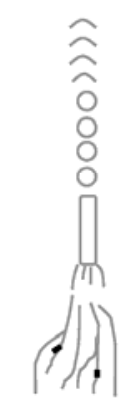

1 wpi (Co-6)

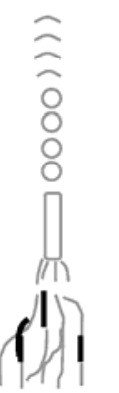

3 wpi (Co-6)

4 wpi (Co-4)

6 wpi (Co-3)

8 wpi (Co-1)

10 wpi (Co-2)

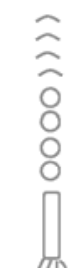

(1)

4 wpi (Co-3)

6 wpi (Co-3)

8 wpi (Co-3)

10 wpi (Co-2)

12 wpi (Co-1)

15 wpi (Co-1)
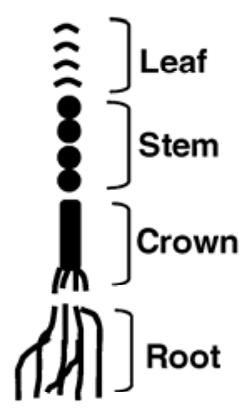

8 wpi (Co-2)

10 wpi (Co-2)

12 wpi (Co-8, Av-3)

15 wpi (Co-9, Av-3, Ro-2)
Legend

Ca Cadenza

Oa Oasis

Cl Claire

Cd Cardinal

Co Consort

Av Avalon

Ro Robigus

SBCMV CP undetected

SBCMV CP detected

\section{B Resistant genotypes}

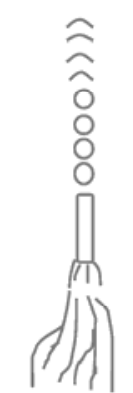

1 wpi (Co-6, Oa-3)

2 wpi (Ca-3, Oa-3)

3 wpi (Oa-1)

5 wpi (Oa-1)

6 wpi (Ca-3, Oa-2)

8 wpi (Ca-4)

12 wpi (Ca-1)

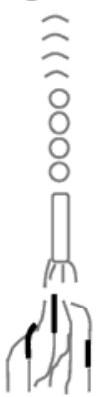

3 wpi (Ca-9, Oa-2)

4 wpi (Ca-9, Oa-3)

5 wpi (Ca-3, Oa-2)

6 wpi (Ca-5, Oa-1)

7 wpi (Ca-2, Oa-3)

8 wpi (Ca-2)

9 wpi (Ca-1, Oa-3)

10 wpi (Ca-2)

11 wpi (Oa-3)

12 wpi (Ca-1)

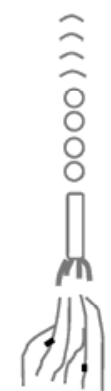

6 wpi (Ca-1)

7 wpi (Ca-2)

9 wpi (Ca-2)

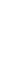

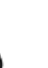
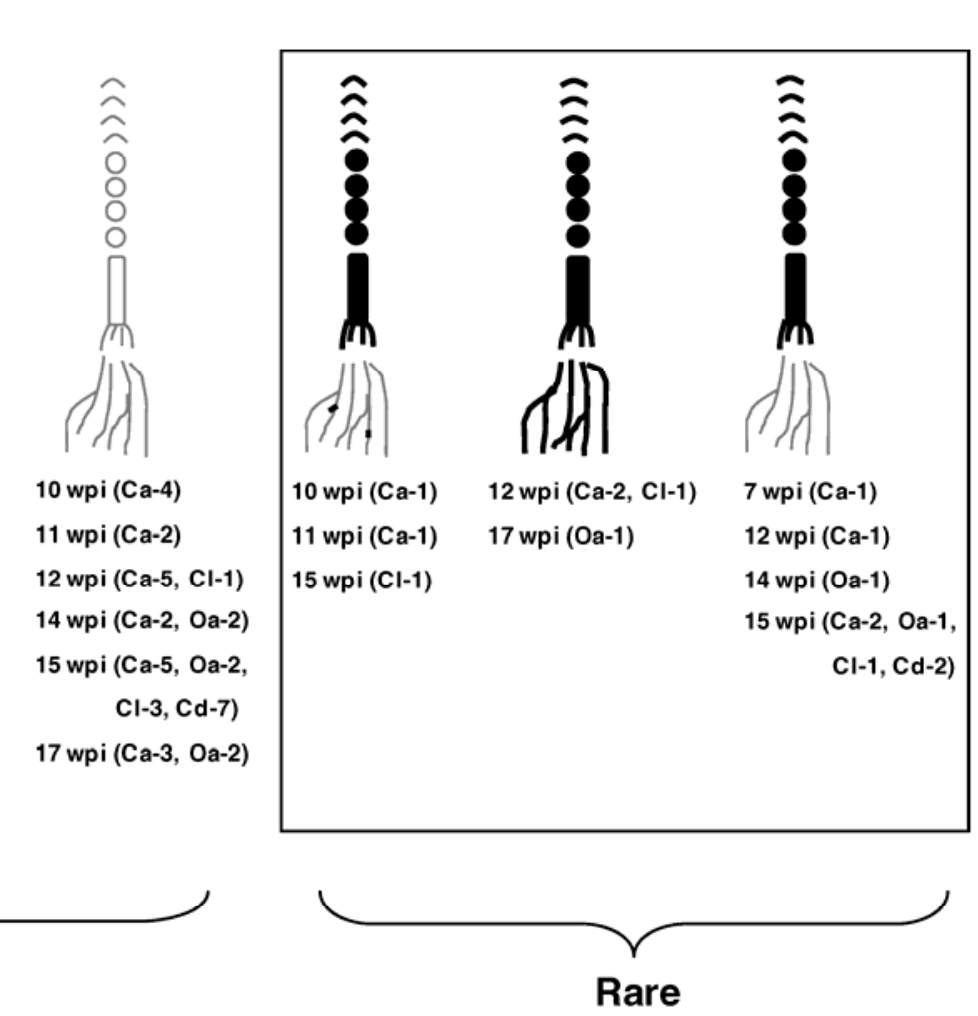

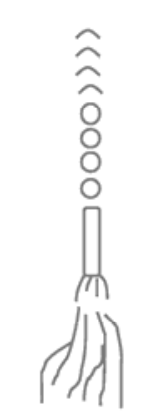

10 wpi (Ca-4)

11 wpi (Ca-2)

12 wpi (Ca-5, Cl-1)

14 wpi (Ca-2, Oa-2)

15 wpi (Ca-5, Oa-2,

Cl-3, Cd-7)

17 wpi (Ca-3, Oa-2)

Rare

Fig. 3. Schematic diagram of the spatiotemporal distribution of Soilborne cereal mosaic virus coat protein (SBCMV CP) in recognized susceptible versus resistant wheat cultivars over a course of infection following soil inoculation. Thick black lines indicate the presence of SBCMV CP as observed in tissueprint immunoassays (TPIAs). Thin gray lines indicate the absence of SBCMV CP in plant tissues. The number of plants of each cultivar which had the indicated phenotype is shown in parentheses. A, Patterns are shown for susceptible cv. Consort (Co) with additional data from the susceptible cultivars Avalon (Av) and Robigus (Ro) at 12 and 15 weeks postinoculation (wpi). B, Resistant cvs. Cadenza (Ca) and Oasis (Oa). Additional TPIA data is included from rare patterns obtained from individuals of resistant cvs. Claire $(\mathrm{Cl})$, Oasis $(\mathrm{Oa})$, and Cardinal $(\mathrm{Cd})$ tested from 7 to 17 wpi. The infection of aerial tissues of resistant cultivars was uncommon, and observations of these rare infection phenotypes are presented in a box. 
Viral RNA is present at reduced levels in roots and in leaves of soil-inoculated individuals of the recognized resistant cv. Cadenza.

The roots of resistant Cadenza and susceptible Consort were collected at $1,3,4,6,8,10,12$, and 15 wpi post soil inoculation and analyzed using SBCMV-specific qRT-PCR. Viral RNA was detected in the roots of all Consort and Cadenza plants at 1 to 15 wpi except for one Cadenza individual at 15 wpi. In Consort individuals, the levels of viral RNA generally increased at every timepoint between 1 and 15 wpi. Statistical analysis of the qRT-PCR data suggested that the level of RNA in the roots of Consort and Cadenza was significantly different over time $(P<0.01)$ (Supplementary Table 3$)$. There was noticeably less viral RNA in the roots of resistant Cadenza than in susceptible Consort at all timepoints (Fig. 5). By 6 wpi, the levels of viral RNA in Cadenza reached the highest point and were comparable with those in Consort individuals sampled at this timepoint (1.25-fold difference) (Fig. 5). However, at 10 wpi and at all the later timepoints, the difference between the levels of viral RNA in Cadenza and Consort became statistically significant $(P<0.05)$. These data are in agreement with the data obtained using TPIA (Fig. 3).

Although the levels of SBCMV RNA reached their peak in the roots of Cadenza at 6 wpi, higher levels of viral RNA were observed in the roots of this cultivar at 12 and 15 wpi (i.e., when viral $\mathrm{CP}$ had disappeared) than at 3 to 4 wpi (i.e., when viral $\mathrm{CP}$ was still present) (Fig. 5). This suggests that virus particle disassembly was initiated in roots of Cadenza (and possibly also in other resistant wheat cultivars) at approximately 8 wpi, resulting in the subsequent degradation of viral CP. This hypothesis is supported by the lack of detectable virus particles using TEM in the roots of Cadenza post 6 wpi (R. Lyons,
A

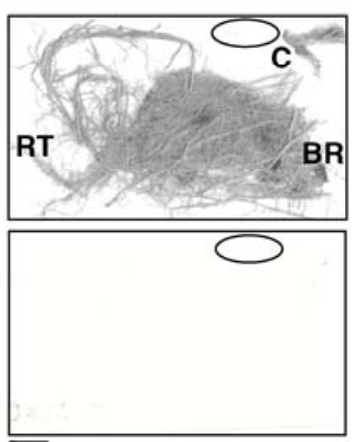

B

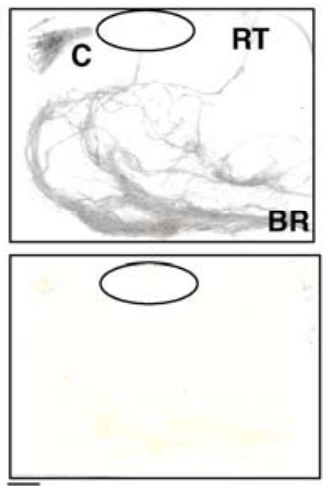

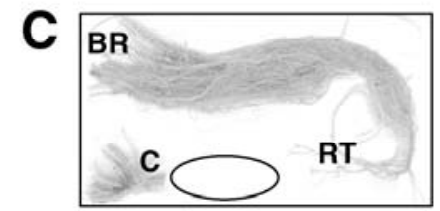
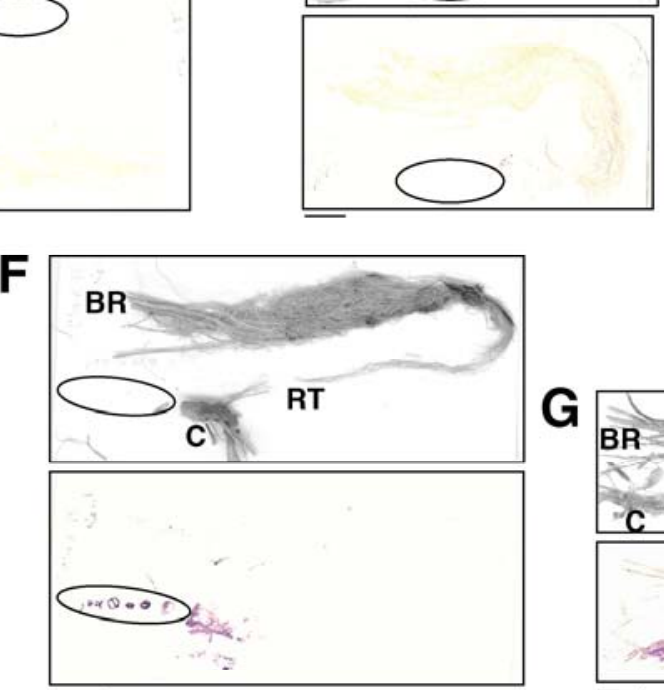

\section{G}
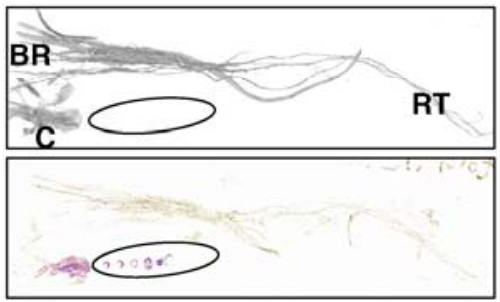

H
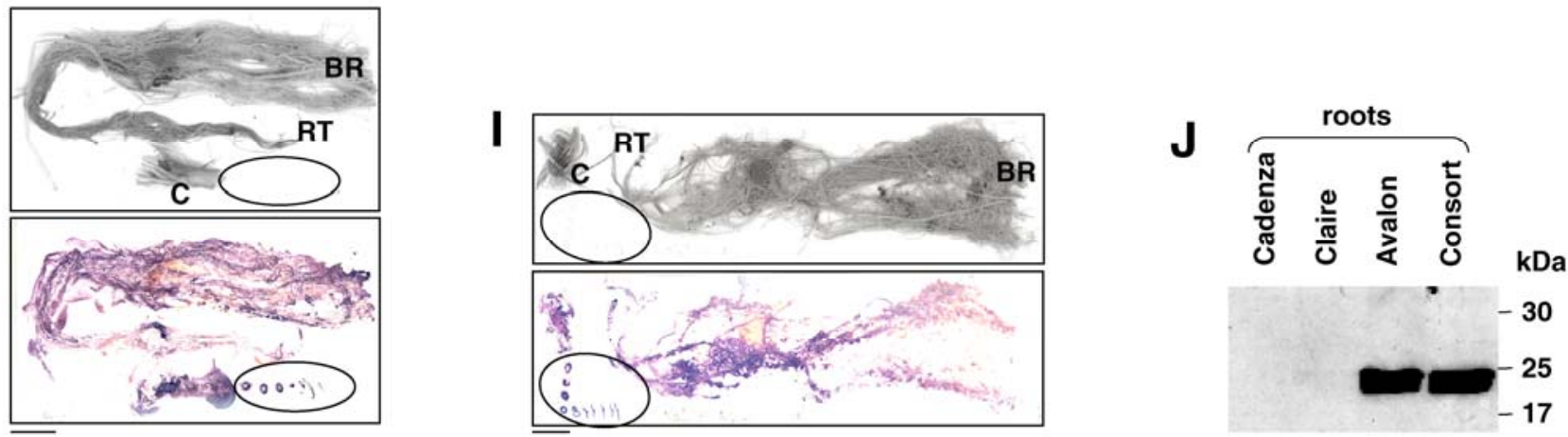

Fig. 4. Analysis of the distribution of Soilborne cereal mosaic virus coat protein (SBCMV CP) in tissues of five additional soil-inoculated wheat cultivars using tissue-print immunoassays (TPIA). All cultivars were examined at 12 weeks postinoculation (wpi) and later timepoints. The top image for each individual plant shows the position of basal roots (BR), root tips (RT), crown (C), and the leaf and stem cross sections (circled). The bottom image for each plant shows the localization of SBCMV CP in soil-inoculated plants (purple coloration). Scale bars (1 cm) are shown for each membrane in the bottom left corner of each panel. A, Winter wheat cv. Oasis (resistant) sampled at 14 wpi; B and C, winter wheat cv. Claire (resistant) sampled at 12 wpi; D, spring wheat cv. Cardinal (resistant) sampled at 15 wpi; E winter wheat Oasis sampled at 12 wpi: the main stem is situated at the right end of the membrane, tillers are placed to the left; F, winter wheat Claire sampled at 15 wpi; G, winter wheat Cardinal sampled at 15 wpi; $\mathbf{H}$, winter wheat cv. Avalon (susceptible) sampled at 15 wpi; I, winter wheat cv. Robigus (susceptible) sampled at 12 wpi; J, Western blot analysis of total root protein extracted from plants inoculated with Kent02 soil: protein extracts were probed with anti-SBCMV immunoglobulin G; total protein staining is shown below each blot; 30-, 25-, and 19-kDa protein standards are indicated. 
unpublished data). Also, the presence of viral RNA in the roots of Cadenza at timepoints when the viral $\mathrm{CP}$ had disappeared suggests that SBCMV RNA continued to replicate, although perhaps to a lesser extent than in susceptible cultivars. The viral RNA probably continued to exist either in a complex with viral movement protein, as has been suggested by Verchot and associates (2001), or as naked RNA.

The majority of Cadenza individuals inoculated with viruliferous soils were resistant to SBCMV, and neither viral $\mathrm{CP}$ nor viral particles were detectable in the leaves of these plants using TPIA (Fig. 3) or TEM (data not shown), respectively. A qRT-PCR analysis was undertaken to determine whether viral RNA was also absent from the leaves of such Cadenza individuals. SBCMV RNA was present at low levels in the leaves of some individuals of the susceptible wheat $\mathrm{cv}$. Consort from as early as 4 wpi but it was absent from all Cadenza individuals tested at this timepoint. From 6 wpi onward, viral RNA was detected in some Consort individuals and also in some Cadenza individuals (Fig. 6). However, the levels of viral RNA increased substantially over time in the leaves of susceptible Consort. In contrast, markedly lower levels of SBCMV RNA were present in the leaves of Cadenza post 6 wpi (Fig. 6).

\section{Cultivars possessing resistance to SBCMV behave as fully} susceptible after manual virus inoculation onto the leaves.

Four weeks post artificial inoculation of leaves of resistant wheat Cadenza and susceptible wheat Consort with SBCMV, mosaic symptoms were apparent on the newly emerging leaves of both cultivars. At 6 wpi, SBCMV CP was detected in shoots and roots of both Consort and Cadenza individuals (Fig. 7A and B), confirming that, similarly to SBWMV, SBCMV readily moved from leaves to roots and accumulated to high levels in the roots of both resistant and susceptible cultivars following virus rub inoculation onto the leaves. There was 600 -fold more SBCMV RNA in the inoculated leaves of Cadenza at 1 wpi than in the roots of individuals of the same wheat genotype at 1 week post soil inoculation (Fig. 7C). By 4 weeks post rub inoculation, the viral RNA had accumulated to extremely high levels in both the young uninoculated leaves and the roots of Consort and Cadenza individuals. The levels of viral RNA in the uninoculated leaves of rub-inoculated Cadenza and Consort plants at 4 and 7 wpi were markedly higher than in the leaves of Consort at 12 weeks post soil inoculation. Therefore, the differential response of resistant Cadenza to SBCMV following natural soil and artificial rub inoculation may be explained, at least in part, by the differences in the quantity of starting virus inoculum applied to plant tissues in two different inoculation procedures.

\section{DISCUSSION}

Several authors have suggested that resistance to SBCMV and SBWMV in wheat is due to a block on viral translocation from roots to shoots (Driskel et al. 2002; Huth et al. 2007; Myers et al. 1993). Results of the spatiotemporal analyses of distribution of SBCMV CP and RNA in tissues of recognized resistant wheat cultivars following soil inoculation reported here suggest that an inhibition of root-to-shoot virus translocation may be a consequence rather than the direct cause of the resistance. We propose that the actual mechanism of resistance to SBCMV in wheat involves the efficient disassembly of virus particles and either an inhibition of further synthesis of viral $\mathrm{CP}$ or its proteolytic degradation. This would leave viral RNA either naked or in a complex with other viral (e.g., movement protein) or host plant proteins. We hypothesize that intact virus

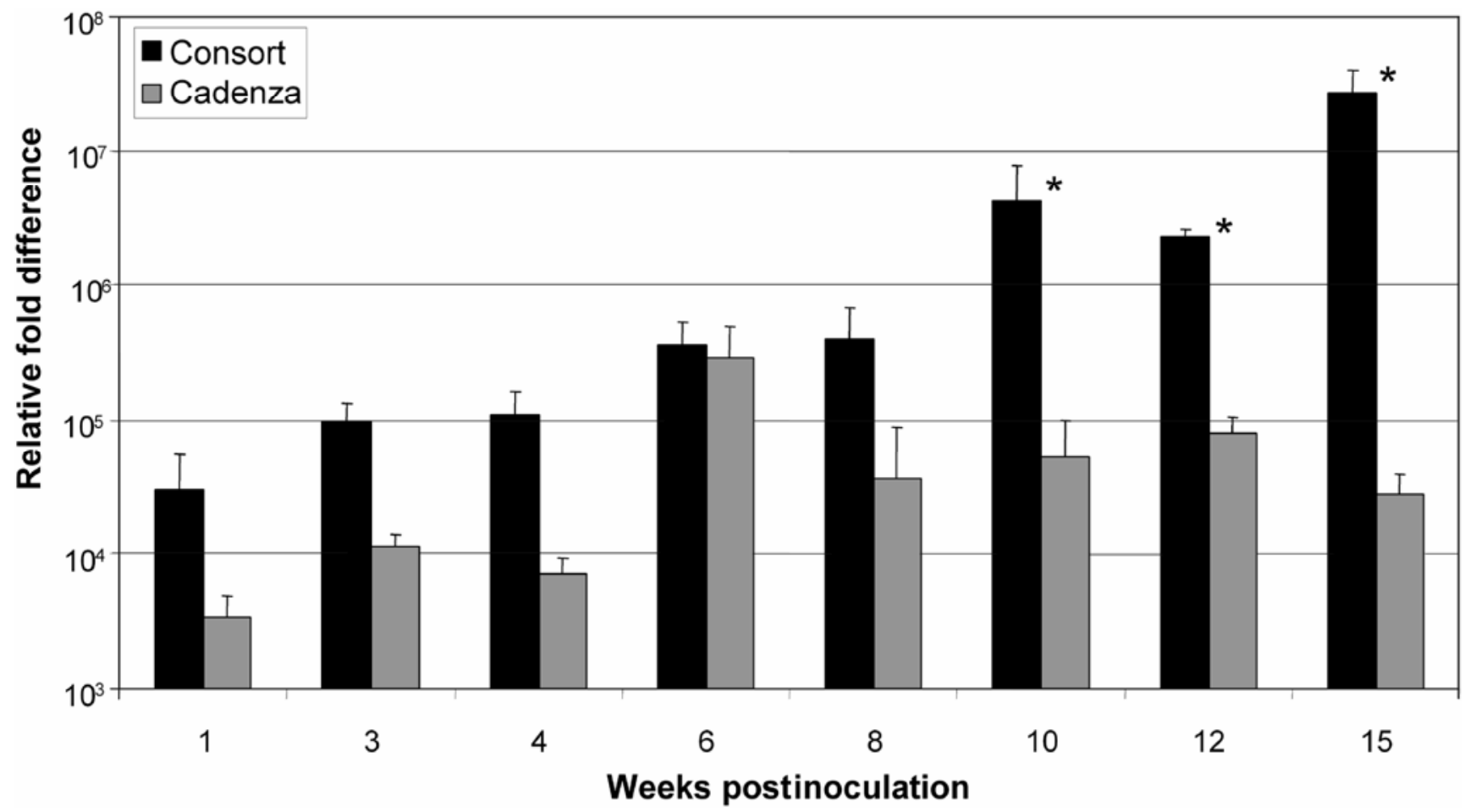

Fig. 5. Mean relative fold changes in viral RNA in the roots of soil-inoculated resistant Cadenza (gray bars) and susceptible Consort (black bars) plants. Data are shown as the mean relative fold change in the levels of Soilborne cereal mosaic virus (SBCMV) RNA detected by quantitative reverse-transcription polymerase chain reaction in roots of Cadenza and Consort individuals collected at 6 timepoints (1, 3, 4, 6, 8, 10, 12, and 15 weeks postinoculation [wpi]). Roots of at least five individuals per cultivar were tested at each timepoint except for wheat Consort at 15 wpi, for which only three individuals were tested. Error bars represent the standard error of the mean of biological replicates. Asterisks indicate that the levels of viral RNA detected were significantly different $(P<$ 0.05 ) between roots of Cadenza and Consort using the least significant difference following the fit of the generalized linear statistical model to log 2 (1/NE) data. 
particles or a viral RNA-CP complex are required for efficient root-to-shoot transport of SBCMV through the vascular system in wheat.

The observed decline in the levels of SBCMV CP in the roots of recognized resistant Triticum aestivum (bread wheat, a hexa- ploid) genotypes during the infection time course is in agreement with previous reports from other laboratories (Hariri et al. 1987; Himmel et al. 1991). It has been noted that roots of resistant wheat grown in SBCMV- or SBWMV-infested fields contained significantly lower levels of furoviral $\mathrm{CP}$ than roots of
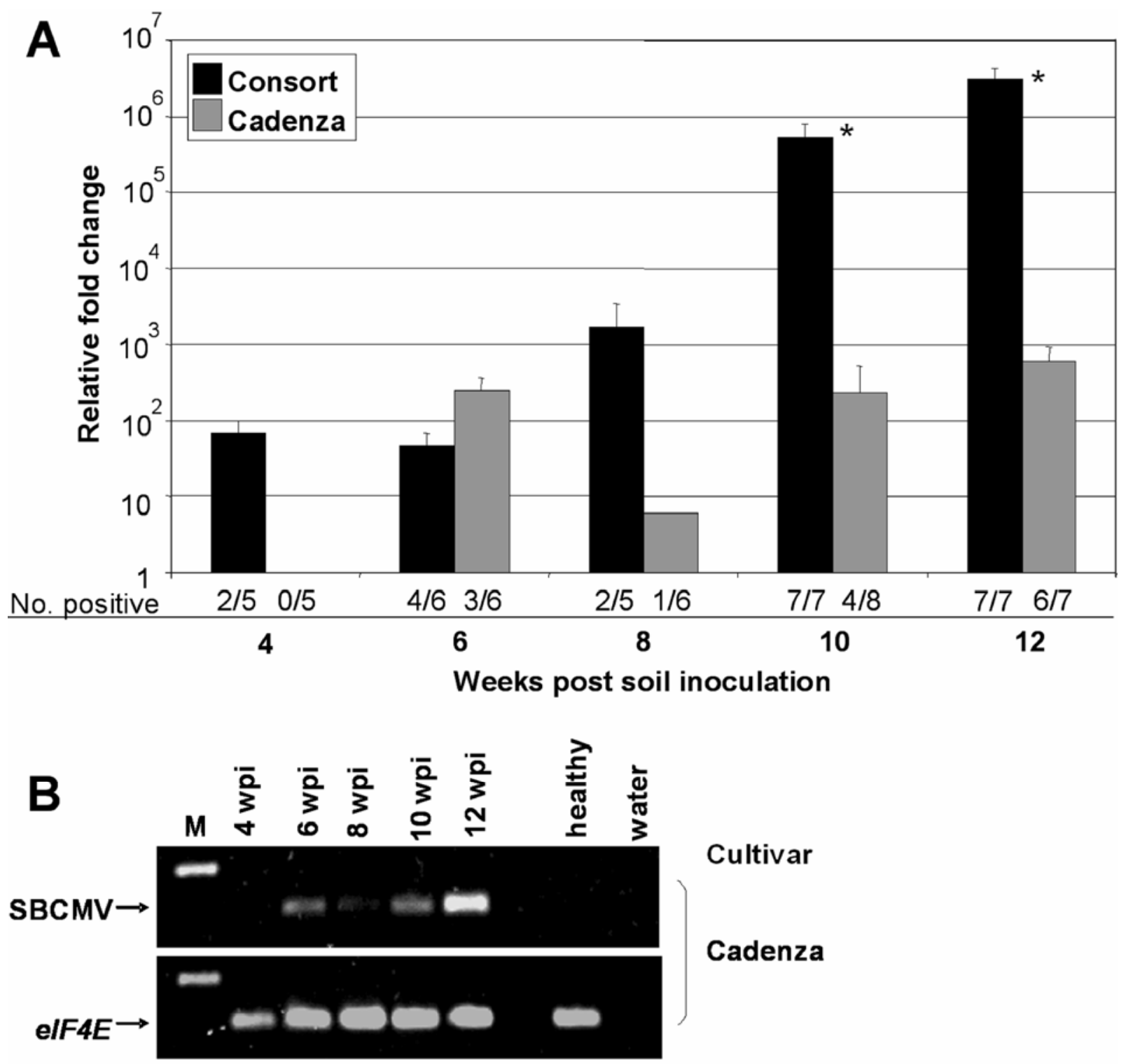

Cultivar
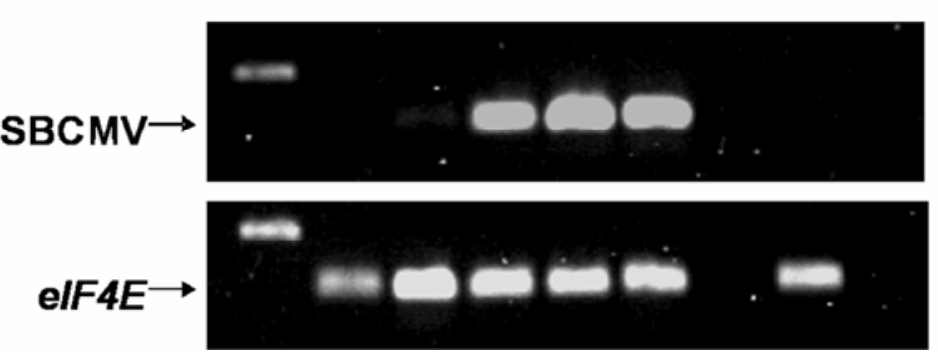

\section{Consort}

Fig. 6. Detection of Soilborne cereal mosaic virus (SBCMV) RNA in the leaves of soil-inoculated susceptible Consort and resistant Cadenza wheat. A, Quantitative reverse-transcription polymerase chain reaction (qRT-PCR) data showing the fold difference in mean normalized levels of SBCMV RNA in the leaves of soil-inoculated Consort and Cadenza plants at five timepoints between 4 and 12 weeks postinoculation (wpi). The proportions in the row labeled "No. positive" immediately below the graph indicates the number of individuals that contained viral RNA out of the total number of individuals tested. Data is shown only for plants that contained viral RNA in the leaves. Plants that lacked viral RNA in the leaves were omitted from the analysis. Error bars represent standard error of the mean of biological replicates. Asterisks indicate that the levels of viral RNA detected were significantly different $(P<0.05)$ between leaves of Cadenza and Consort using the least significant difference following the fit of the generalized linear model to $\log _{2}$ ( $\left.1 / \mathrm{NE}\right)$ data (Supplementary Table 4). B, Gel electrophoresis of qRT-PCR products. For each timepoint, the eIF4E and SBCMV qRT-PCR products from an individual plant containing the highest level of SBCMV RNA was loaded, except for Consort at 4 wpi, where no product was detected. M: DNA marker (100-bp GeneRuler, Fermentas); the 100-bp DNA fragment is visible. The expected size of all qRT-PCR products was $71 \mathrm{bp}$. 
the susceptible wheat genotypes at the end but not at the beginning of the growing season. In contrast, resistance in $T$. durum (pasta or macaroni wheat, a tetraploid) has been suggested to operate by inhibiting SBCMV accumulation throughout the plant and immediately after transmission to plant roots by $P$. graminis (Vallega et al. 2006). However, the levels of viral RNA in the roots of the plants subjected to the resistance tests have not been quantified in these previous studies.

In a recent report by Lunello and associates (2007), it has been suggested that a developmentally linked, transient loss of viral CP from the roots of Arabidopsis thaliana plants infected by either of the two distinct RNA viruses, Turnip mosaic virus (genus Potyvirus) and Oilseed rape mosaic virus (genus Tobamovirus), is consistent with a loss of virus particles due to disassembly (Lunello et al. 2007). No clear, direct (i.e., electron microscopic) evidence for the disassembly of SBCMV particles in the roots of soil-inoculated resistant wheat genotypes was found in our study; however, the virus particles were only observed at 6 wpi post soil inoculation in the roots of resistant Cadenza. A distribution of SBCMV virus particles modal lengths ranging from approximately 45 to $400 \mathrm{~nm}$ was observed. The presence of shorter virus particles in the Cadenza root sap, in our opinion, does not necessarily indicates the SBCMV particle disassembly because a similar range of modal lengths (from approximately 50 to $420 \mathrm{~nm}$ ) for particles of a related virus, SBWMV, has been observed in susceptible wheat genotypes in earlier studies by others (Gumpf 1971; Shirako and Brakke 1984; Tsuchizaki et al. 1975). Furovirus particles are fragile (ICTVdB Management 2006); therefore, shorter particles may have resulted from breakage due to mechanical stress involved in sap expression from plant tissues.
Western blot analyses of total protein from roots of soilinoculated resistant Cadenza wheat showed that the viral $\mathrm{CP}$ gradually disappears from the roots of this genotype by 8 wpi. No specific proteolytic cleavage or post-translational modification of SBCMV CP in the roots of resistant Cadenza wheat was evident, as has been reported, for example, for the $30 \mathrm{~K}$ movement protein of Tobacco mosaic virus (TMV) in infected tobacco protoplasts (Reichel and Beachy 2000). However, in another recent study, it has been found that in planta ubiquitinylation prevents the immunodetection of important epitopes on TMV CP by CP-specific antibodies (Hamacher et al. 2003). It seems possible that this was also the case for SBCMV CP detection in our study. Moreover, most of the ubiquitin conjugates detected using Western blots in young tobacco leaves infected with TMV have been suggested to be due to ubiquitinylated TMV CP. As a consequence, a considerable amount of TMV CP cannot be used for correct virus particle construction because the stabilizing amino acid residues are blocked by ubiquitinylation (Hamacher et al. 2003). If a similar mechanism exists in the roots of SBCMV-infected resistant wheat Cadenza, this may explain the apparent "disappearance" of SBCMV CP and intact virus particles during the course of infection.

Our current model on the mechanism of resistance to SBCMV in wheat is based on the assumption that encapsidation of furoviral RNA is required for its efficient systemic movement, whereas cell-to-cell movement is achieved in a CPindependent manner. Although this has not yet been experimentally demonstrated for SBCMV or SBWMV, the above assumption seems reasonable because plant viruses, with only a few exceptions, require virus particle formation for long-distance transport (Callaway et al. 2001; Carrington et al. 1996)
A

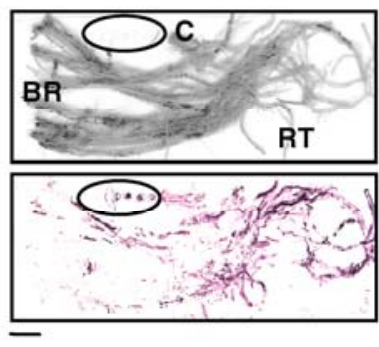

B

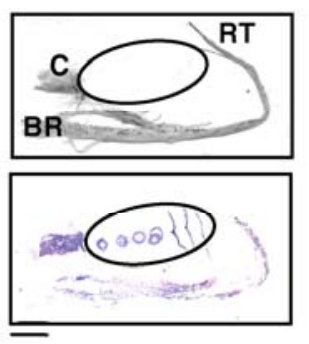

C

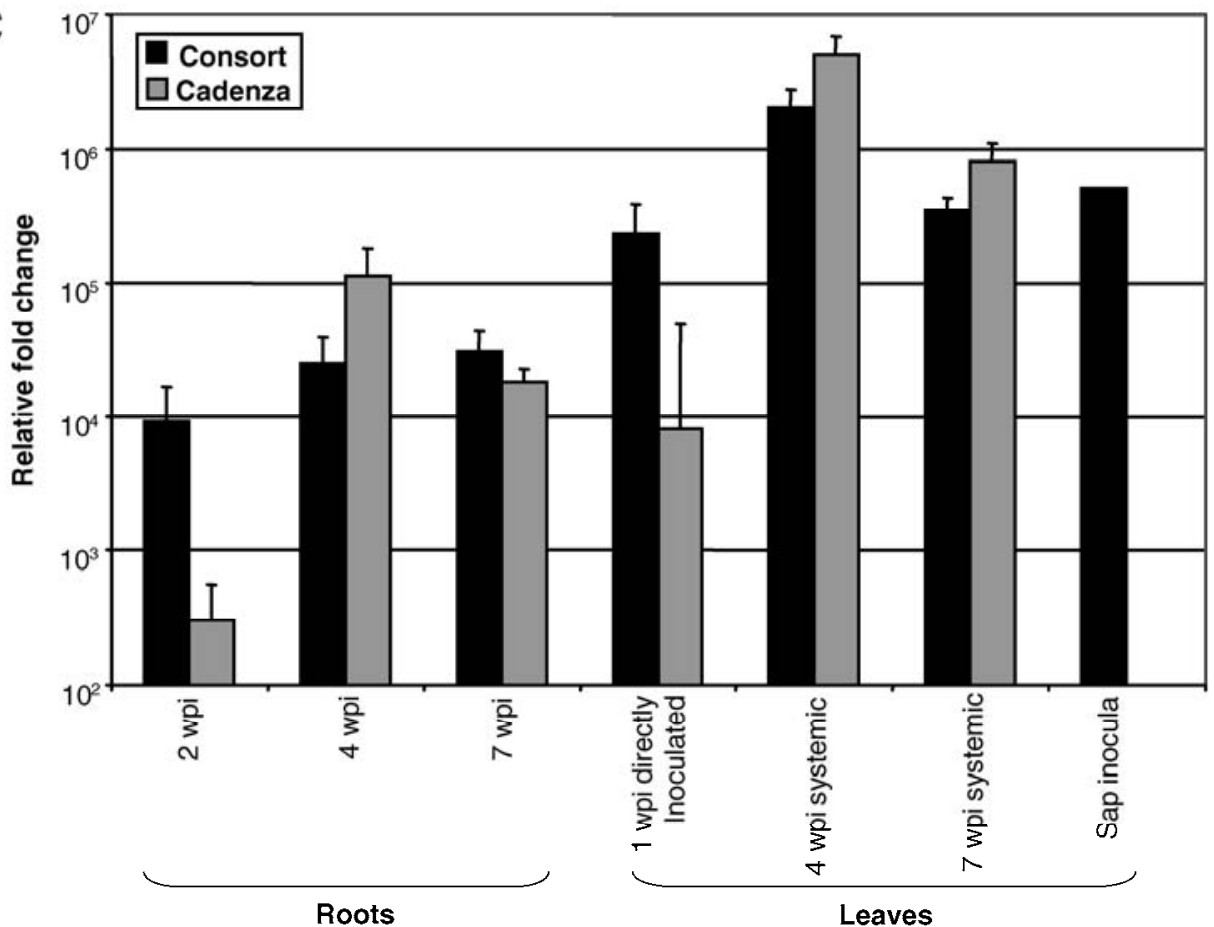

Fig. 7. Analysis of the spatiotemporal distribution of Soilborne cereal mosaic virus coat protein (SBCMV CP) and RNA in mechanically inoculated susceptible Consort and resistant Cadenza wheat. Tissue-print immunoassays (TPIAs) for detection of SBCMV coat protein in A, Consort and B, Cadenza at 6 weeks post rub inoculation of leaves with SBCMV-Kent. The top image for each plant shows the position of basal roots (BR), root tips (RT), crown (C), and stem and leaf cross sections (circled) on the membrane prior to immunolocalization. The bottom image for each plant shows the localization of SBCMV CP (purple coloration). Scale bars are $1 \mathrm{~cm}$ in length. $\mathbf{C}$, Quantitative reverse-transcription polymerase chain reaction data showing the fold difference in mean normalized levels of SBCMV RNA in the roots and young uninoculated leaves of rub-inoculated Consort and Cadenza plants at 2 (roots only), 4, and 7 weeks postinoculation (wpi), as well as the leaf sap used for inoculation and the directly inoculated leaves of plants collected at 1 wpi. Error bars represent standard error of the mean of biological replicates. 
whereas this generally is not required for cell-to-cell movement of the rod-shaped plant viruses (Callaway et al. 2001). Moreover, even in the rare cases where the $\mathrm{CP}$ gene is partially or completely dispensable for systemic transport of the viruses, the time required for systemic infection is often dramatically increased in its absence (Scholthof 2005). The presence of only low levels of SBCMV RNA in the leaves of soil-inoculated resistant Cadenza plants, roots of which contained undetectable levels of viral $\mathrm{CP}$, suggests that long-distance movement of furoviral RNA in the absence of CP is severely restricted..

Breakdown of resistance to SBCMV, which was manifested by typical leaf symptoms and the accumulation of SBCMV RNA and CP to high levels in the leaves, was observed in 4, 10 , and $12 \%$ of individuals of recognized resistant wheat cvs. Cardinal, Cadenza, and Claire, respectively. When SBCMV $\mathrm{CP}$ was detected in the leaves of these individuals using TPIA, it was ubiquitous within the infected tillers, and intact virus particles were detected in the leaves. Therefore, it appears that resistance to SBCMV in aerial tissues is compromised. This hypothesis is also supported by the observation that resistant wheat cultivars behave as fully susceptible when their leaves are artificially inoculated with furoviruses.

Breakdown of resistance to both isolates of SBCMV used in this study was observed. This phenomenon also has been reported for other SBCMV as well as SBWMV isolates in previous studies by others (Armitage et al. 1990; Budge et al. 2008; Driskel et al. 2002; Himmel et al. 1991). Unfortunately, the exact factors influencing breakdown of resistance to Furovirus spp. in wheat remain unknown. The single factor that was positively correlated with the incidence rate of resistance breakdown in this study was the frequency of infection in the susceptible wheat cvs. Avalon and Consort (Table 1).

It has been suggested by several authors that resistance to SBCMV and SBWMV is overcome in the presence of the Bymovirus WSSMV (Cadle-Davidson et al. 2005; Lapierre et al. 1995; Lommel and Willis 1984; Lommel et al. 1986). However, in this study, WSSMV was found neither in individuals whose resistance to SBCMV had been compromised nor in fully susceptible individuals. In addition, the experimental evidence obtained in this study did not support our initial hypothesis that the breakdown of resistance to SBCMV is the result of prohibitively high levels of viruliferous $P$. graminis in the starting soil inoculum. Incidence rates of resistance breakdown were similar among individuals inoculated with the standard inoculum, which comprised 1 part of soil and 2 parts of sand and the individuals inoculated with the serially diluted inoculum, which comprised 1 part of soil and up to 20 parts of sand. Moreover, the concentration of $P$. graminis in the roots of infected plants was uncorrelated with the presence or absence of SBCMV CP in their leaves. Similar data has been obtained in a study on sugar beet resistance to BNYVV, which is transmitted by $P$. betae, a species closely related to $P$. graminis. That is, the amount of $P$. betae resting spores in the roots of resistant and susceptible sugar beet cultivars has been shown to be similar (Tuitert et al. 1994). The caveat is that only a small proportion of the Polymyxa spp. present in the soil are likely to be viruliferous (Chen et al. 1991), whereas diagnostic assays used by Tuitert and associates (1994) and in this study did not discriminate between viruliferous and nonviruliferous Polymyxa spp. Moreover, the roots assayed for the presence of $P$. graminis in this study for technical reasons were only collected from individual plants harvested at 14 weeks post soil inoculation and not at any earlier timepoint postinoculation. Direct inoculation of wheat roots with a controlled number of SBCMV-containing $P$. graminis zoospores would be an ideal method of testing the effect of starting inoculum concentration on the incidence rate of resistance breakdown. However, the obligate biotrophic nature of $P$. graminis makes this procedure extremely challenging to carry out.

An additional hypothesis to explain the aerial tissue invasion by SBCMV in a small proportion of individuals of recognized resistant Cadenza was that these underwent the developmental switch between vegetative and reproductive growth later than the rest (majority/norm). Ethyl methanesulfonate (EMS)mutagenized Cadenza $\mathrm{M}_{4}$ families selected for differences in the heading dates were tested for their reaction to SBCMV using soil inoculation under glasshouse conditions. No positive correlation between the late heading and the incidence of resistance breakdown was found (R. Lyons, unpublished data).

It is possible that plants grown in particular experiments where resistance was broken (Table 1) were exposed to some kind of abiotic or additional biotic stress which compromised or weakened the plant's basal defenses. The soils used in this study were collected directly from fields with a recent history of wheat cultivation (Budge et al. 2008) and may have contained other soilborne pathogens of wheat. Compromised defense responses caused by the presence of other organisms in wheat roots may have permitted the establishment and reproduction of $P$. graminis which ultimately resulted in enhanced accumulation of SBCMV. A diversion of host resources away from antiviral defense may have allowed intact virus particles to accumulate to higher levels and to persist for a longer time in the roots of resistant cultivars prior to their resistanceinduced disassembly. This would have allowed SBCMV to travel systemically to the leaves and accumulate there to high levels. Interestingly, most of the Cadenza, Claire, and Oasis individuals in which the antiviral resistance was broken (i.e., those containing SBCMV in the leaves) lacked viral $\mathrm{CP}$ in their roots. Therefore, by 8 to $12 \mathrm{wpi}$, the time when SBCMV $\mathrm{CP}$ was first detected in leaves of a small proportion of individuals of recognized resistant cultivars, these individuals would seem to have already recovered from the initial stress and the resistance would have been fully operational in their roots. Alternatively, by 8 to $12 \mathrm{wpi}$, the flow of virus with the photosynthetic assimilates from the source leaves to roots may have been inefficient. It is plausible that they were already being redirected to the more active sink organs (i.e., the flag leaves and developing ears).

The influence of the environment on resistance to Furovirus spp. has been noted by several research groups (Armitage et al. 1990; Barbosa et al. 2001; McKinney 1931; Modawi et al. 1982). For example, it has been shown that the systemic infection of both SBWMV-susceptible and -resistant wheat cultivars increases with temperature (Driskel et al. 2002; Myers et al. 1993) and that SBWMV transmission is influenced by soil moisture and temperature (Cadle-Davidson and Bergstrom 2004; Cadle-Davidson et al. 2003). The glasshouse compartment temperature and soil-watering regime were the same for all experiments in this study, but the amount of daylight and small fluctuations in air or soil temperature were uncontrolled and, therefore, may have accounted for some phenotypic variability.

Unfortunately, TPIA, qRT-PCR, and qPCR are all destructive procedures. Therefore, the interpretation of the spatiotemporal distribution of SBCMV CP and RNA was based on the comparison of separate plants at the different timepoints rather than studying the kinetics of viral infection within individual plants. However, the testing of several replicate plants at each timepoint by TPIA in this study allowed us to obtain an accurate representation of the diversity of phenotypes exhibited between inoculated plant individuals.

If SBCMV and SBWMV disease pressure increases in cereals, the epidemiological and economical impact of resistance breakdown for agriculture will become apparent. This study 
highlights the need for new, more efficient sources of resistance to Furovirus spp. for use in wheat breeding programs.

\section{MATERIALS AND METHODS}

\section{Biological materials.}

Soils were collected from highly infested patches of fields in Wiltshire, U.K. in 2004 (SBCMV-Wilt04) and 2005 (SBCMVWilt05) and from Kent, U.K. in 2002 (SBCMV-Kent02) as described previously (Bass et al. 2006). Wiltshire soils were fine loam over clay whereas the Kent soil was fine silt over clay (Mackney et al. 1983). Before use, all soils were manually mixed and passed through a coarse sieve to obtain uniform inoculum. Soils were stored dry in the dark at $4^{\circ} \mathrm{C}$ until use.

Seed of the U.K. wheat cvs. Cadenza, Cardinal, Claire, Consort, and Avalon was sourced from the Biotechnology and Biological Sciences Research Council Small Grain Cereal Collections, John Innes Centre, Norwich, U.K. Seed of the North American wheat cv. Oasis was sourced from the National Small Grains Collection (NSGC), United States Department of Agriculture-Agricultural Research Service, Aberdeen, ID, U.S.A.

\section{Natural (soil) inoculation of plants with Furovirus spp.}

Plants were inoculated with infested soils as described previously (Kanyuka et al. 2004) in a controlled temperature glasshouse at $16^{\circ} \mathrm{C}$ (night) to 17 to $20^{\circ} \mathrm{C}$ (day) $\pm 2{ }^{\circ} \mathrm{C}$ with a 16 -h photoperiod.

Experiment 1 (testing the hypothesis that the breakdown of resistance to SBCMV in recognized resistant U.K. wheat cultivars was caused by an exceedingly high concentration of starting inoculum) was conducted in November 2005 to January 2006. The three viruliferous soils SBCMV-Wilt04, SBCMVWilt05, and SBCMV-Kent02 were mixed with sand in ratios (soil/sand) of 1:2, 1:5, 1:10, and 1:20. Four seedlings of the SBCMV-susceptible wheat cvs. Consort or Avalon or the SBCMV-resistant cvs. Cardinal, Cadenza, or Claire were planted per pot of each soil/sand mix. Three replicate pots were prepared for each cultivar per soil batch. Pots were placed in individual trays for watering, to avoid potential cross-contamination with free-swimming zoospores.

Experiment 2 (exploring possible differences in host responses to the three viruliferous soil batches) was undertaken in December 2006 to February 2007. The three SBCMVinfested U.K. soil batches were mixed with sand in a ratio of 1:10 (soil/sand). Three replicate pots, each containing four seedlings of one of the five cultivars (tested in experiment 1) were prepared for each soil batch. Pots were placed in individual trays for watering to avoid potential cross-contamination with free-swimming zoospores. As an extra precaution against splash contamination, each soil batch (i.e., SBCMVWilt04, SBCMV-Wilt05, or SBCMV-Kent02) was placed on a separate randomly allocated bench. Therefore, the pots were placed in completely randomized designs on three separate benches but with environmental differences between benches being negligible.

For both experiments, the number of soil-inoculated plants that contained SBCMV CP antigen in the leaves was determined using indirect $\mathrm{F}\left(\mathrm{ab}^{\prime}\right)_{2}$ ELISA at three timepoints between 6 and 11 wpi essentially as described by Lyons and associates (2008).

\section{Statistical analyses of ELISA data \\ from soil inoculation experiments 1 and 2.}

The number of plants which contained SBCMV CP antigen in the leaves out of the total number of plants grown in each pot for each soil batch was fitted to a generalized linear model (McCullagh and Nelder 1989) using Genstat release 11.1
(VSN International Ltd., Hemel Hempstead, U.K.). The assumption was made that the number of infected plants in a given pot was binomially distributed (i.e., the data was comprised of discrete random variables) as $\operatorname{Bin}(n, p)$ where $n=$ total number of inoculated plants and $p=$ number of leafinfected plants. Our aim was to test whether the $p$ value obtained depended upon wheat cultivar, soil, or dilution rate of soil inocula or an interaction between pairs of or all three of these factors. The data from experiments 1 and 2 was fitted to the following final model: $\ln \left(p_{i j k} /\left(1-p_{i j k}\right)\right)=\mu+C_{i}+D_{j}+S_{k}+$ $E_{i j k}$, where $\ln =$ natural $\log , p_{i j k}=$ probability of infection for pot $i j k$, and the other model terms $\mu=$ constant, $C_{i}=$ wheat cultivar $i\left(i=1,2,3,4\right.$, and 5 for the five wheat cultivars), $D_{j}=\mathrm{di}-$ lution rate $j$ of soil inocula $(j=1,2,3$, and 4 for the four serial soil dilutions with sand), $S_{k}=$ soil $k(k=1,2$, and 3 for the three soil inoculum batches), and $E_{i j k}=$ error for fitting data from pot $i j k$.

The significance of model terms was tested using the change in model deviance upon the sequential addition of these terms (employing the principle of forward selection). This is distributed as $\chi^{2}$ on the corresponding degrees of freedom for the particular term. There was no overdispersion of the data (variability above that which would be expected for the assumption of a binomial distribution to be permissible). The estimated parameters (treatment effects) of significant terms in the fitted model were then investigated to consider appropriate comparisons of wheat cultivars, soil, and dilution rate of soil inocula.

Data generated from experiments 1 and 2 were then combined and analyzed to determine whether the particular soil or wheat cultivar significantly influenced the likelihood of SBCMV invasion of foliar tissues. The final model (using a logit link) was: $\ln \left(p_{i j k} /\left(1-p_{i j k}\right)\right)=\mu+\operatorname{Exp}_{1}+C_{i}+D_{j}+S_{k}+$ $(\operatorname{Exp} \times S)_{\mathrm{lk}}+E_{i j k}$, where all model terms were as above, except $\operatorname{Exp}_{l}=$ experiment $l(l=1,2)$ and $(\operatorname{Exp} \times S)$ representing the interaction between experiment and soil.

\section{Detection of virus particles using TEM.}

Fresh leaves were ground with water $(0.3 \mathrm{~g}$ of plant tissue per $1 \mathrm{ml}$ of distilled water). The sap was centrifuged at maximum speed for $1 \mathrm{~min}$ and the supernatant was mixed with an equal volume of $2 \%$ phosphotungstic acid (vol/vol). The mixture was then sprayed onto Formvar/carbon-coated $\mathrm{Cu}$ electron microscope grids. Grids were then examined under the transmission electron microscope 2011 FasTEM (JEOL Ltd., Tokyo) operating at $200 \mathrm{kV}$ for the presence of virus particles. For each grid, at least three fields of approximately $200 \mu \mathrm{m}^{2}$ were viewed. Images were captured using the US1000 (Gatan Inc., Warrendale, PA, U.S.A.) high-resolution cooled CCD camera and virus particles dimensions were measured using Digital Micrograph software (Gatan Inc.).

\section{Detection of WSSMV using conventional RT-PCR.}

Primers Fw4 and Rw4 (Gitton et al. 1999) were used to amplify a 456-bp fragment corresponding to WSSMV RNA 1 using a one-step RT-PCR. A 3.5- $\mu \mathrm{g}$ aliquot of total RNA was added to each reaction mixture which contained $400 \mathrm{nM}$ forward and reverse primers, $1 \times$ ThermoScript Reaction Mix, Taq enzyme mix at $2 \mathrm{U} / \mu \mathrm{l}$ (Platinum Quantitative RT-PCR Thermoscript One-Step System; Invitrogen, Ltd., Paisley, Scotland) and RnaseOut at $0.8 \mathrm{U} / \mu \mathrm{l}$ (Invitrogen). First-strand synthesis was carried out at $50^{\circ} \mathrm{C}$ for $30 \mathrm{~min}$ and was immediately followed by PCR. Cycling conditions were $2 \mathrm{~min}$ at $95^{\circ} \mathrm{C}$; then, 35 cycles of $15 \mathrm{~s}$ at $95^{\circ} \mathrm{C}, 30 \mathrm{~s}$ at $56^{\circ} \mathrm{C}$, and 1 min at $72^{\circ} \mathrm{C}$; followed by $10 \mathrm{~min}$ at $72^{\circ} \mathrm{C}$. The WSSMVinfected wheat leaves used as the positive control were a gift from U. Kastirr (Julius Kuehn-Institute, Quedlinburg, Germany). 
Quantification of $P$. graminis in the roots of soil-inoculated wheat plants using QPCR.

To compare the amount of $P$. graminis in roots of soil-inoculated wheat plants, DNA was extracted from finely ground lyophilized roots and used as a template for quantitative PCR as described previously (Ward et al. 2005). Each $25-\mu \mathrm{l}$ reaction contained $100 \mathrm{ng}$ of plant root DNA, $1 \times$ Jumpstart Taq Readymix (Sigma-Aldrich Ltd., Gillingham, U.K.), $8 \times$ reference dye (Sigma-Aldrich Ltd.), $0.6 \mu \mathrm{M}$ primer PxRealF, 0.2 $\mu \mathrm{M}$ primer PxRealR, and $0.15 \mu \mathrm{M}$ of the TaqMan probe PgRealP, which was labeled at the $5^{\prime}$ end with the fluorescent reporter dye FAM (6-carboxy-fluoroscein). The cycling parameters were $2 \mathrm{~min}$ at $95^{\circ} \mathrm{C}$ followed by 50 cycles of $15 \mathrm{~s}$ at $95^{\circ} \mathrm{C}$ and $1 \mathrm{~min}$ at $60^{\circ} \mathrm{C}$. Cycle values at threshold fluorescence were obtained using the ABI PRISM Sequence Detector software (version 1.2.1; Applied Biosystems, Foster City, CA, U.S.A.). All samples and standards were tested in duplicate.

\section{Analysis of the spatiotemporal distribution of SBCMV CP in soil-inoculated resistant and susceptible genotypes using TPIA.}

For the initial time-course experiment, the recognized resistant wheat cvs. Cadenza (Kanyuka et al. 2004) and Oasis (Modawi et al. 1982), and the susceptible wheat cv. Red Chief (Modawi et al. 1982) were used. Plants were inoculated with SBCMV-Wilt04 soil mixed with sand in a ratio of $1: 2$ (soil/sand). Three soil-inoculated plants of each cultivar were sampled and tested for the presence of SBCMV CP using TPIA at $1,2,3,4,5,6,7,9,11,14,15$, and 17 wpi. TPIA was performed as described previously (Lyons et al. 2008).

Subsequently, we discovered that the seed stock of Red Chief was impure and, therefore, a follow-up rime-course experiment was done using resistant Cadenza and the recognized susceptible cv. Consort (Kanyuka et al. 2004). Three soilinoculated plants of each cultivar were sampled and tested for the presence of SBCMV CP at 1, 3, 4, 6, 8, 10, 12, and 15 wpi using TPIA. This experiment was then repeated so that all TPIA data generated was combined from biological replicates within and between the two replicate experiments. Selected individuals of the wheat cultivars from soil-inoculation experiments 1 and 2 (see above) were also subjected to TPIA at 12 to 17 wpi.

\section{Analysis of the spatiotemporal distribution of viral RNA in soil-inoculated resistant and susceptible genotypes using qRT-PCR.}

Total RNA was extracted from i) roots of soil-inoculated susceptible Consort and resistant Cadenza individuals at 1, 3, $4,6,8,10,12$, and $15 \mathrm{wpi}$; ii) leaves of the same individuals at $4,6,8,10$, and $12 \mathrm{wpi}$; and iii) roots and leaves of individuals rub inoculated with the virus to the leaves at $1,2,4$, and 7 wpi using TRIzol reagent (Invitrogen) according to the manufacturer's instructions. Levels of SBCMV RNA in these total RNA samples were analyzed using qRT-PCR with primers qSBCMV-F and qSBCMV-R located in the CP cistron on RNA2 of SBCMV as described previously (Lyons et al. 2008). At least five biological replicates were tested for each cultivar at each timepoint, except for the roots of soil-inoculated Consort at 15 wpi and the artificially inoculated tissues, for which only three biological replicates were tested. Normalized expression (NE) values for all samples were calculated relative to the mean NE value for the leaves of soil-inoculated Cadenza plants collected at 8 wpi, because this sample contained the lowest level of viral RNA relative to the endogenous housekeeping control gene $e I F 4 E$, which was used as the reference gene for normalization. $\log _{2}(1 / \mathrm{NE})$ transformed data were modeled using a generalized linear model to assess the statisti- cal significance of the wheat cultivar, wpi, and the interaction of these two factors using Genstat (release 11.1; VSN International Ltd., Hemel Hempstead, U.K.). Predicted means from the fitted model were compared using the least significant difference at the $5 \%$ level.

\section{Western blot analysis.}

A quantity of $300 \mu \mathrm{l}$ of extraction buffer $(25 \mathrm{mM}$ Tris- $\mathrm{HCl}$, $\mathrm{pH} 7.8 ; 75 \mathrm{mM} \mathrm{NaCl} ; 15 \mathrm{mM}$ EDTA; $0.1 \%$ Tween $20 ; 100 \mu \mathrm{l}$ of dithiothreitol; $0.005 \mathrm{M}$ phenymethyl sulphonyl fluoride; leupeptin at $1 \mathrm{mg} / \mathrm{ml}$; and aprotinin at $1 \mathrm{mg} / \mathrm{ml}$ ) was added to $100 \mathrm{mg}$ of finely ground freeze-dried roots and ground further with a mortar and pestle. The homogenates were transferred to 1.5-ml Eppendorf tubes and clarified by centrifugation at $13,000 \times g$ for $15 \mathrm{~min}$ at $4^{\circ} \mathrm{C}$. The supernatants were used directly for Western blot analyses. Total protein was quantified using a commercially available Bradford assay (BioRad Laboratories, Ltd., Hemel Hempstead, U.K.) according to the manufacturer's instructions. Protein absorbance at $595 \mathrm{~nm}$ was compared with the protein standard, bovine serum albumin (2 $\mathrm{mg} / \mathrm{ml}$ ).

Approximately $40 \mu \mathrm{g}$ of total protein was separated on $13 \%$ sodium dodecyl sulfate polyacrylamide gel electrophoresis gels and electroblotted onto Hybond ECL nitrocellulose (GE Healthcare, Amersham, U.K.). Protein transfer was confirmed by staining the blot with $0.5 \%$ Ponceau $\mathrm{S}$ solution before the membrane was incubated in blocking solution (1× Tris-buffered saline [20 mM Tris- $\mathrm{HCl}, 150 \mathrm{mM} \mathrm{NaCl}], 5 \%$ dry baby milk powder, and $0.1 \%$ Tween 20 ) overnight at $4^{\circ} \mathrm{C}$. Blots were probed with polyclonal anti-SBCMV immunoglobulin G (IgG) at $1 \mu \mathrm{g} / \mu \mathrm{l}$ and, subsequently, a 1:10,000 dilution of antirabbit IgG horseradish peroxidase conjugate (Sigma-Aldrich Ltd.). Blots were developed using ECL Plus Western Blotting Detection System (GE Healthcare).

\section{ACKNOWLEDGMENTS}

We thank J. Devonshire, Center for Bioimaging, Rothamsted Research, for analyzing the TEM grids. Rothamsted Research receives grant-aided support from the Biotechnology and Biological Sciences Research Council (BBSRC) of the United Kingdom. R. Lyons was supported by a BBSRC quota studentship awarded to Rothamsted Research.

\section{LITERATURE CITED}

Armitage, C. R., Hunger, R. M., Sherwood, J. L., and Weeks, D. L. 1990. Relationship between development of hard red winter wheat and expression of resistance to Wheat soilborne mosaic virus. Plant Dis. 74:356-359.

Barbosa, M. M., Goulart, L. R., Prestes, A. M., and Juliatti, F. C. 2001. Genetic control of resistance to Soilborne wheat mosaic virus in Brazilian cultivars of Triticum aestivum L. Thell. Euphytica 122:417-422.

Bass, C., Hendley, R., Hammond-Kosack, K., and Kanyuka, K. 2006. The Sbm1 locus conferring resistance to Soilborne cereal mosaic virus maps to a gene-rich region of 5DL in wheat. Genome 49:1140-1148.

Brakke, M. K., and Langenberg, W. G. 1988. Experiences with Soilborne wheat mosaic virus in North America and elsewhere. Pages 183-202 in: Developments in Applied Biology II. Viruses with Fungal Vectors. J. I. Cooper and M. J. C. Asher, eds. Association of Applied Biologists, Wellesbourne, U.K.

Budge, G. E., Ratti, C., Rubies-Autonell, C., Lockley, D., Bonnefoy, M., Vallega, V., Pietravalle, S., and Henry, C. M. 2008. Response of UK winter wheat cultivars to Soilborne cereal mosaic and Wheat spindle streak mosaic viruses across Europe. Eur. J. Plant Pathol. 120:259-272.

Cadle-Davidson, L., and Bergstrom, G. C. 2004. The effects of postplanting environment on the incidence of soilborne viral diseases in winter cereals. Phytopathology 94:527-534.

Cadle-Davidson, L., Schindelbeck, R. R., van Es, H. M., Gray, S. M., and Bergstrom, G. C. 2003. Using air pressure cells to evaluate the effect of soil environment on the transmission of soilborne viruses of wheat. Phytopathology 93:1131-1136.

Cadle-Davidson, L., Bergstrom, G. C., and Cox, T. S. 2005. Susceptibility 
of perennial small grains to Soilborne wheat mosaic virus and Wheat spindle streak mosaic virus. Plant Health Prog. doi:10.1094/PHP-20051130-01-BR. Published online.

Cadle-Davidson, L., Sorrells, M. E., Gray, S. M., and Bergstrom, G. C. 2006. Identification of small grains genotypes resistant to Soilborne wheat mosaic virus. Plant Dis. 90:1039-1044.

Callaway, A., Giesman-Cookmeyer, D., Gillock, E. T., Sit, T. L., and Lommel, S. A. 2001. The multifunctional capsid proteins of plant RNA viruses. Annu. Rev. Phytopathol. 39:419-460.

Carrington, J. C., Kasschau, K. D., Mahajan, S. K., and Schaad, M. C. 1996. Cell-to-cell and long-distance transport of viruses in plants. Plant Cell 8:1669-1681.

Carroll, J. E., Bergstrom, G. C., and Gray, S. M. 2002. Assessing the resistance of winter wheat to Wheat spindle streak mosaic bymovirus. Can. J. Plant Pathol. 24:465-470.

Chain, F., Riault, G., Trottet, M., and Jacquot, E. 2005. Analysis of accumulation patterns of Barley yellow dwarf virus-PAV (BYDV-PAV) in two resistant wheat lines. Eur. J. Plant Pathol. 113:343-355.

Chen, J. 1993. Occurrence of fungally transmitted wheat mosaic viruses in China. Ann. Appl. Biol. 123:55-61.

Chen, J. P., Swaby, A. G., Adams, M. J., and Yilli, R. 1991. Barley mild mosaic virus inside its fungal vector, Polymyxa graminis. Ann. Appl. Biol. 118:615-621.

Driskel, B. A., Hunger, R. M., Payton, M. E., and Verchot-Lubicz, J. 2002. Response of hard red winter wheat to Soilborne wheat mosaic virus using novel inoculation methods. Phytopathology 92:347-354.

Gill, G. 2004. Mosaic virus detected in Canterbury wheat field. Biosecurity $54: 17$

Gitton, F., Diao, A., Ducrot, O., Antoniw, J. F., Adams, M. J., and Maraite, H. 1999. A two-step multiplex RT-PCR method for simultaneous detection of Soilborne wheat mosaic virus and Wheat spindle streak mosaic virus from France. Plant Pathol. 48:635-641.

Gumpf, D. J. 1971. Purification and properties of Soilborne wheat mosaic virus. Virology 43:588-596.

Hamacher, J., Wettern, M., and Schulz, M. 2003. Ubiquitination of TMV coat protein aggregates in infected tobacco leaves. J. Phytopathol. 151:652-659.

Hariri, D., Courtillot, M., Zaoui, P., and Lapierre, H. 1987. Multiplication of Soilborne wheat mosaic virus (SBWMV) in wheat roots infected by a soil carrying SBWMV and Wheat yellow mosaic virus (WYMV). Agronomie 7:789-796.

Hariri, D., Meyer, M., and Prud'homme, H. 2003. Characterization of a new Barley mild mosaic virus pathotype in France. Eur. J. Plant Pathol. 109:921-928.

Hariri, J., and Meyer, M. 2007. A new Furovirus infecting barley in France closely related to the Japanese Soilborne wheat mosaic virus. Eur. J. Plant Pathol. 118:1-10.

Himmel, P. T., Hewings, A. D., and Glawe, D. A. 1991. Incidence of Soilborne wheat mosaic virus and its reported vector, Polymyxa graminis, in field-grown soft red winter wheat. Plant Dis. 75:1008-1012.

Hunger, R. M., Armitage, C. R., and Sherwood, J. L. 1989. Effects of wheat soilborne mosaic virus on hard red winter wheat. Plant Dis. 73:949-952.

Huth, W., Lesemann, D. E., and Goetz, R. 2005. Translocation resistance-most effective type of resistance to Furoviruses of wheat. Pages 78-80 in: Proc. Sixth Symp. Int. Working Group on Plant Viruses with Fungal Vectors. C. M. Rush, ed. American Society of Sugar Beet Technologists, Denver

Huth, W., Gotz, R., and Lesemann, D. E. 2007. Different types of resistance to soilborne viruses of wheat. Gesunde Pflanz. 59:29-39.

ICTVdB Management. 2006. 00.027.0.01.001. Soilborne wheat mosaic virus. In: ICTVdB-The Universal Virus Database, version 4. C. Büchen-Osmond, ed. Columbia University, New York.

Kanyuka, K., Lovell, D. J., Mitrofanova, O. P., Hammond-Kosack, K., and Adams, M. J. 2004. A controlled environment test for resistance to Soilborne cereal mosaic virus (SBCMV) and its use to determine the mode of inheritance of resistance in wheat cv. Cadenza and for screening Triticum monococcum genotypes for sources of SBCMV resistance. Plant Pathol. 53:154-160.

Kapooria, R. G., Ndunguru, J., and Clover, G. R. G. 2000. First reports of Soilborne wheat mosaic virus and Wheat spindle streak mosaic virus in Africa. Plant Dis. 84:921.

Khan, A. A., Bergstrom, G. C., Nelson, J. C., and Sorrells, M. E. 2000. Identification of RFLP markers for resistance to wheat spindle streak mosaic bymovirus (WSSMV) disease. Genome 43:477-482.

Koenig, R., and Huth, W. 2000. Soilborne rye mosaic and European wheat mosaic virus: Two names for a furovirus with variable genome properties which is widely distributed in several cereal crops in Europe. Arch. Virol. 145:689-697.

Koenig, R., and Huth, W. 2003. Natural infection of wheat by the type strain of Soilborne wheat mosaic virus in a field in Southern Germany. Eur. J. Plant Pathol. 109:191-193.

Kühne, T., Shi, N., Proeseler, G., Adams, M. J., and Kanyuka, K. 2003. The ability of a bymovirus to overcome the rym4-mediated resistance in barley correlates with a codon change in the VPg coding region on RNA1. J. Gen. Virol. 84:2853-2859.

Kumari, S. G., and Makkouk, K. M. 2003. Differentiation among Bean leafroll virus susceptible and resistant lentil and faba bean genotypes on the basis of virus movement and multiplication. J. Phytopathol. 151:1925 .

Larsen, R. M., Brakke, M. K., and Langenberg, W. G. 1985. Relationships between Wheat spindle streak mosaic virus and Soilborne wheat mosaic virus infection, disease resistance, and early growth of winter wheat. Plant Dis. 69:857-862.

Lapierre, H., Prud'homme, H., Fouchard, H., Lebrun, L., and Hariri, D. 1995. Assistance to long distance transport between Wheat yellow mosaic virus (WYMV) and Soilborne wheat mosaic virus (SBWMV) in bread wheat cultivars resistant to WYMV. Agronomie 15:505-506.

Liu, H. Y., and Lewellen, R. T. 2007. Distribution and molecular characterization of resistance-breaking isolates of Beet necrotic yellow vein virus in the United States. Plant Dis. 91:847-851.

Lommel, S. A., and Willis, W. G. 1984. The role of Wheat spindle streak and Wheat soilborne mosaic viruses in an epiphytotic of resistant wheat in Kansas. Phytopathology 74:844-844.

Lommel, S. A., Willis, W. G., and Kendall, T. L. 1986. Identification of Wheat spindle streak mosaic virus and its role in a new disease of winter wheat in Kansas. Plant Dis. 70:964-968.

Lunello, P., Mansilla, C., Sánchez, F., and Ponz, F. 2007. A developmentally linked, dramatic, and transient loss of virus from roots of Arabidopsis thaliana plants infected by either of two RNA viruses. Mol. Plant-Microbe Interact. 20:1589-1595.

Lyons, R., Hammond-Kosack, K. E., and Kanyuka, K. 2008. Identification and characterization of a novel efficient resistance response to the Furoviruses SBWMV and SBCMV in barley. Mol. Plant-Microbe Interact. 21:1193-204.

Mackney, D., Hodgson, J. M., Hollis, J. M., and Staines, S. J. 1983. Legend for the 1:250,000 Soil Map of England and Wales. Soil Survey of England and Wales, Rothamsted Experimental Station, Harpenden, U.K.

McCullagh, P., and Nelder, J. A. 1989. Generalized Linear Models. 2nd ed. Chapman and Hall, New York.

McGrann, G. R. D., and Adams, M. J. 2004. Investigating resistance to Barley mild mosaic virus. Plant Pathol. 53:161-169.

McKinney, H. H. 1931. Differentiation of viruses causing green and yellow mosaics of wheat. Science 73:650-651.

McKinney, H. H. 1937. Mosaic disease of wheat and related cereals. U. S. Dep. Agric. Circ. 442:23.

McKinney, H. H. 1948. Wheats immune from soilborne mosaic viruses in the field, susceptible when inoculated manually. Phytopathology 38:1003-1013.

Modawi, R. S., Heyne, E. G., Brunetta, D., and Willis, W. G. 1982. Genetic studies of field reaction to Wheat soilborne mosaic virus. Plant Dis. 66:1183-1184.

Myers, L. D., Sherwood, J. L., Siegerist, W. C., and Hunger, R. M. 1993. Temperature-influenced virus movement in expression of resistance to Soilborne wheat mosaic virus in hard red winter wheat (Triticum aestivum). Phytopathology 83:548-551.

Nakagawa, M., Soga, Y., Watanabe, S., Gocho, H., and Nishio, K. 1959. Genetical studies on the wheat mosaic virus. II. Genes affecting the inheritance of susceptibility to strains of yellow mosaic virus in varietal crosses of wheat. Jpn. J. Breed. 9:118-120.

Percival, J. 1921. The Wheat Plant. Duckworth and Co., London.

Reichel, C., and Beachy, R. N. 2000. Degradation of Tobacco mosaic virus movement protein by the $26 \mathrm{~S}$ proteasome. J. Virol. 74:3330-3337.

Rubies-Autonell, C., and Vallega, V. 1987. Observations on a mixed Soilborne wheat mosaic virus and Wheat spindle streak mosaic virus infection in durum wheat (Triticum durum Desf.). J. Phytopathol. 119:111121.

Scholthof, H. 2005. Plant virus transport: Motions of functional equivalence. Trends Plant Sci. 10:376-382.

Sergeant, E. P. 1964. Cocksfoot mottle virus. Plant Pathol. 13:23-24

Shirako, Y., and Brakke, M. K. 1984. Two purified RNA's of Soilborne wheat mosaic virus are needed for infection. J. Gen. Virol. 65:119-127.

Tsuchizaki, T., Hibino, H., and Saito, Y. 1975. Biological functions of short and long particles of Soilborne wheat mosaic virus. Phytopathology 65:523-532.

Tuitert, G., Vanoorschot, P. M. S. M., and Heijbroek, W. 1994. Effect of sugar beet cultivars with different levels of resistance to Beet necrotic yellow vein virus on transmission of virus by Polymyxa betae. Eur. J. Plant Pathol. 100:201-220.

Vallega, V., Rubies-Autonell, C., Turina, M., Ratti, C., and Contoli, S. 
1999. Reactions of durum wheat cultivars to infections by SBWMV grown in northern Italy during 1995-96. Z. Pflanzenkrankh. Pflanzenschutz 106:284-290.

Vallega, V., Rubies-Autonell, C., and Ratti, C. 2006. Resistance to accumulation of Soilborne cereal mosaic virus in eight cultivars of Triticum durum Desf. Parasitica 62:79-96.

Varrelmann, M. 2007. Occurrence, spread and pathogenicity of different forms of the Rhizomania virus (Beet necrotic yellow vein virus, BNYVV) - review on biology and variability of Rhizomania and on detection of isolates possibly overcoming resistance. Zuckerindustrie 132:113-120.

Verchot, J., Driskel, B. A., Zhu, Y., Hunger, R. M., and Littlefield, L. J. 2001. Evidence that Soilborne wheat mosaic virus moves long distance through the xylem in wheat. Protoplasma 218:57-66.

Ward, E., Kanyuka, K., Motteram, J., Kornyukhin, D., and Adams, M. J. 2005. The use of conventional and quantitative real-time PCR assays for Polymyxa graminis to examine host plant resistance, inoculum levels and intraspecific variation. New Phytol. 165:875-885.

\section{AUTHOR-RECOMMENDED INTERNET RESOURCES}

The International Working Group on Plant Viruses With Fungal Vectors (IWGPVFV) website:

www.rothamsted.bbsrc.ac.uk/ppi/Iwgpvfv/index.html Descriptions of Plant Viruses (DPV) website: www.dpvweb.net 